\title{
Türkçenin Yabancı Dil Olarak Öğretiminde Metin Türlerinin Sınıflandırılması ve Ders Kitaplarında Yer Alan Okuma Metinlerinin Değerlendirilmesi*
}

\section{The Classification of Text Types and The Evaluation of Reading Passages Available in Course Books in Teaching Turkish as A Foreign Language}

\author{
Latif ILTAR $^{1}$ (1), Fatma AÇIK ${ }^{2}$ (1)
}

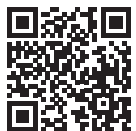

*Bu çalışma "Türkçenin Yabancı Dil Olarak Öğretiminde Kullanılan Ders Kitaplarındaki Okuma Metinlerinin Farklı Değișkenler Açııından Değerlendirilmesi" adlı doktora tezinden üretilmiştir.

${ }^{1}$ Sorumlu yazar/Corresponding author: Latif iltar (Dr.),

Ankara Yıldırım Beyazıt Üniversitesi, Dil Eğitimi Uygulama ve Araștırma Merkezi, Ankara, Türkiye

E-posta: liltar@ybu.edu.tr

ORCID: 0000-0002-2807-8083

${ }^{2}$ Fatma Açık (Prof. Dr.),

Gazi Üniversitesi, Eğitim Fakültesi, Türkçe Eğitimi

Anabilim Dalı, Ankara, Türkiye

ORCID: 0000-0002-3972-0799

Başvuru/Submitted: 22.07.2019

Revizyon Talebi/Revision Requested:

02.09.2019

Son Revizyon/Last Revision Received:

10.09.2019

Kabul/Accepted: 25.09.2019

Online Yayın/Published Online: 11.12.2019

Atıf/Citation: Iltar Latif ve Acik, Fatma.

"Türkçenin Yabancı Dil Olarak Öğretiminde Metin Türlerinin Sınıflandırılması ve Ders Kitaplarında Yer Alan Okuma Metinlerinin

Değerlendirilmesi." Türkiyat Mecmuası-Journal of Turkology 29, 2 (2019): 311-346.

https://doi.org/10.26650/iuturkiyat.658073

\section{ÖZ}

Dil öğretiminde metinler, dört temel dil becerisinin kazandırılmasında kullanılan en temel araç olarak karşımıza çıkmaktadır. Bu sebeple metinlerin dil öğrenicisine kazandırılmak istenen yeterlikleri karşılaması ve özenle seçilmiş olması beklenir. Metin türlerine ait sınıflandırmalarda görüş birliği sağlanamadığı ve farklı sınıflandırmaların yapılmış olduğu görülür. Araştırmacılar tarafından kendi çalışma alanlarına uygun olarak yapılan sınıflandırmaların dil öğretimi alanı açısından birtakım eksiklikler içerdiği görülmektedir. Bu sebeple özellikle yabancı dil öğretimi açısından kullanılabilecek bir metin türü sınıflandırmasının yapılması gerekmektedir. Yabancı dil öğretiminde kazandırılmak istenen yeterlilikler öğrenicinin seviyesine ve ön bilgilerine göre farklılıklar göstermektedir. Metinler de türlerine göre farklı dil özellikleri ve anlatımlar içerdiğinden metin türlerinin kullanılabileceği seviyelerin birbirinden farklılık göstermesi beklenir. Bu çalışmada öncelikle dil öğretiminde kullanılabilecek metin türlerinin bir sınıflandırması yapılmış akabinde bu sınıflandırmaya uygun olarak Yedi İklim Türkçe Öğretim Seti ile İstanbul Yabancılar İçin Türkçe Öğretim Seti'nde yer alan okuma metinleri nitel araştırma yöntemi esas alınarak doküman analizi tekniği ile tespit edilmiş ve karşılaştırılmıştır. Çalışmada son olarak hangi metin türünün hangi seviyede kullanılabileceği ile ilgili öneriler sunulmuştur.

Anahtar kelimeler: Türkçenin yabancı dil olarak öğretimi, metin sınıflandırması, okuma, okuma metinleri, Türkçe öğretim setleri

\section{ABSTRACT}

In language teaching, reading texts stand as the most fundamental instrument used in the acquisition of four basic language skills. For this reason, texts are expected to meet the qualifications that are meant for the language student and be well-selected. In the classifications related to text types, there exist cases in which no consensus has been arrived at or different categorizations have been made. It is observed that the classifications made by researchers in accordance with their own field of study involve several inadequacies with regard to the field of foreign language teaching. Therefore, a certain type of reading text classification 
to be particularly used in teaching a foreign language is required.

The competencies aimed at in foreign language teaching vary in relation to the level and background information of the learner. As reading texts contain different language characteristics and expressions in terms of their types, the levels in which text types can be used are anticipated to differ from one another. In this study, a categorization of text types that can be used in language teaching has been primarily made, the reading passages involved in Yedi İlim Turkish Teaching Set and İstanbul Turkish Teaching Set for Foreigners have been analyzed and compared based on this classification in the second place, and finally, suggestions have been made upon which text type might be used in which level.

Keywords: Teaching Turkish as a foreign language, text classification, reading, reading texts, Turkish teaching sets

\section{EXTENDED ABSTRACT}

While, in the first reading phase, reading as a language skill appears in the form of learning how the systematics of reading functions by making sense of certain writing symbols, it turns out to be the most fundamental means of acquiring knowledge and developing language in the later stages. Texts stand out as the most essential instrument used in the acquisition of four basic language skills in foreign language education. The reading passages used in both native language education and teaching Turkish as a foreign language are primarily regarded as teaching aids and materials. In Turkish teaching process, all texts ranging from the low-level texts such as warning and instruction signs on undergrounds and buses to the literary texts that involve deep meanings like poems have their own area of use in language education. For instance, in teaching Turkish to foreigners, a dialogue between a ticket officer and a passenger in the stage of buying a ticket for the underground or a column in a newspaper assumes a textual quality. Similarly, a poetry text containing figurative language and literary phrases or a text conveying information about a topic related to Turkish culture in a course book involves a textual characteristic with respect to a specific language skill. In other words, each meaning element that can be read, listened, written or spoken has a textual feature in terms of language teaching.

Reading basically has the aim of communication and certain types of factors are present in the process of reading. These factors include the author, the text, the reader and the feedbacks. The most significant of all these during the process are the reading texts. In this respect, texts occupy a highly important place in teaching Turkish as a foreign language. The texts are not only involved in reading skill but also frequently used in the development stages of other language skills. When the sets designed to teach Turkish as a foreign language are closely examined, it is observed that the majority of the texts available in course books is made up of reading passages. As for the activities related to other language skills, a great majority of them is associated with the reading texts and their formation is based on the texts in question. To cite an example, in an activity aimed at the development of writing or reading skill, a dialogue or story text is given to the students to be read and they are asked to continue the text by speaking or writing.

When texts are analyzed in terms of their types, it is seen that no association is present among the researchers with regard to the classifications of text types and that the categorizations have been achieved by the researchers in quite different ways. Despite the fact that each text classification 
is consistent and meaningful in itself, a variety of text type classification has come up due to the differences between the researchers' points of view. Concerning language teaching, however, the concepts of texts and text types differ from the related classifications in some aspects. The reason for this is that the text to be used in the teaching of language involves a material quality. In this way, it is possible to regard every teaching material which can achieve the objectives and acquirements as a text.

When the studies conducted upon text classifications are examined, it is observed that the related categorizations contain certain defects in terms of the field of language teaching. This being the case, a text type classification that can be used in language teaching has been performed in this study. In accordance with this classification, texts are divided into two as texts based on the aim of formation and those based on their functions. The former is also separated into two groups as fictional texts aimed directly at language teaching and original texts intended for the daily use of native language speakers and used indirectly in foreign language teaching. The texts formed on the basis of their functions, on the other hand, have been analyzed in terms of writing purpose and language use and gathered under two main titles as texts with utility function and literary texts. The original texts involved in the texts classified in accordance with their aim of formation are also divided into two in themselves as daily texts and literary texts. The daily texts contain such passages like menus, tickets, posters, warranty certificates and graffiti that are prepared with no aesthetic concern and that assign native language readers as their target group. As for the literary texts, they include novels, stories, tales, legends, etc that are put down on paper with an aesthetic concern and with native language readers being their target group. With respect to the texts based on their functions, the texts with utility function refer to all reading materials that can be readily experienced in daily life and that neither involve literary value in terms of the aim of writing or use of language nor aesthetic concern. The texts with utility function have been gathered within themselves under three titles as formal, instructive and communicative texts. The literary texts are those that are formed with an aesthetic concern in relation to the aim of writing and language use. These texts are also titled in three ways within themselves as instructive texts, texts based on expression/demonstration and poetry.

Apart from the classification of text types, this study involves, as well, the analysis and comparison of the reading texts available in Yedi İklim Turkish Teaching Set and İstanbul Turkish Teaching Set for Foreigners along with recommendations related to which text type might be used in which language level. 


\section{Giriş}

Okuma, ilk okuma evresinde bazı yazı sembollerinin anlamlandırılmasıyken daha sonraları bilgiyi edinmenin ve dili geliştirmenin en temel yolu olarak karşımıza çıkmaktadır. Okuma ile ilgili birçok tanım bulunmaktadır. Bu tanımların genel özelliklerine göre okuma; görme, algılama, seslendirme ve anlama sürecidir. ${ }^{1}$

Ana dili ve yabancı dil eğitim-öğretim faaliyetleri içerisinde dört temel dil becerisine eşit oranda yer verilmesi gerekiyor olsa da ders materyalleri incelendiğinde içerik olarak okuma becerisine ait ders materyallerinin diğer dil becerilerine ait ders materyallerinden daha fazla yer kapladığı görülür. Mesela Korkmaz, okuma metinlerinin metin işleme süreleri bakımından dinleme metinlerine göre Yedi İklim Türkçe Öğretim Seti (YİTÖS)'nde \%400, İstanbul Yabancılar İçin Türkçe Öğretim Seti (İTÖS)'nde \%500 oranında daha fazla olduğunu tespit etmiştir. ${ }^{2}$

Bebeklikten okul çağına kadar geçen süre içerisinde ana dillerine ilişkin olarak dinleme ve konuşma becerisinde ilerlemeler katetmiş olanlar için okuma ve yazma becerisi ilk aşamada ilk okuma ve yazma öğretimi ile başlamaktadır. Sonrasında da öğrenciler ağırlıklı olarak okuma ve yazma becerilerini geliştirebilme yolunda eğitime devam etmektedir. Ana dilinde dil becerilerini geliştirmek hayat boyu devam eden bir süreçtir. Yabancı dil öğreniminde veya ikinci dil ediniminde dil becerilerinin kazanılması ve geliştirilmesi ana dilinde olduğundan çok daha farklıdır. Burada dili edinen veya öğrenen hedef kitlenin yaşı belirleyicidir. Yabancı dil öğrenimi veya ikinci dil edinimi sırasında okuma becerisinin geliştirilmesi, ana dilinde okuma bilen öğrenim çağındaki bireyler için benzer süreci ifade ederken yetişkin gruplar ve daha küçük yaş grupları için uygulanacak öğretim faaliyetleri ve kullanılacak öğretim malzemeleri farklılık gösterir. Yabancı dil öğretim setleri incelendiği zaman ders kitaplarında yer alan metinlerin büyük çoğunluğunun okuma metinlerinden oluştuğu görülür. Diğer dil becerileriyle ilgili etkinliklerin ise büyük çoğunluğunun okuma metinleriyle ilişkili olduğu ve bu okuma metinlerinden yararlanılarak etkinliklerin oluşturulduğu gözlenir.

Okuma, temelde bir iletişim amacı taşımaktadır ve okuma sürecinde birtakım unsurlar bulunmaktadır. Okuma sürecinde yer alan unsuları; yazar, metin, okuyucu ve geri dönütler oluşturmaktadır. Süreç içerisinde bu unsurlardan en önemlisi metindir. Bu bakımdan metinler yabancı dil olarak Türkçe öğretiminde oldukça önemli yer tutmaktadır. Metinler sadece okuma becerisi için değil aynı zamanda diğer dil becerilerinin geliştirilmesi aşamalarında da sıklıkla kullanılmaktadır.

\section{Metin}

Metin; bir yazıyı oluşturan seslerin, kelimelerin, cümlelerin, paragrafların yazar tarafından

1 Cavit Kavcar, vd., Türkçe Öğretimi (Ankara: Engin,1998), 41., Ahmet Saraçoğlu, Dil ve Edebiyat Terimleri Sözlüğü, (Eskişehir: Etam, 2000), 205., Feyzi M. Öz, Uygulamalı Türkçe Öğretimi (Ankara: An1, 2001), 193., Firdevs Güneş, Türkçe Ögrretimi ve Zihinsel Yapılandırma, (Ankara: Nobel, 2007), 117., Özcan Demirel, Yabancı Dil Öğretimi (Ankara: Pegem, 2012), 109.

2 Cihat Burak Korkmaz, "Yabancı Dil Olarak Türkçenin Öğretiminde Kullanılan Dinleme Metinlerinin Metin İşleme Süreleri”, International Journal of Languages Education and Teaching 7/1, (2019), 121-146. 
bilinçli olarak bir araya getirilerek oluşturulduğu dil düzenlemeleridir. ${ }^{3}$ Ders kitaplarında yer alan metinlerin hedeflemesi gereken amaçlar ve cevap vermesi gereken ihtiyaçlar vardır. $\mathrm{Bu}$ amaç ve ihtiyaçlar şunlardır:

- Bilgi aktarma: Öğrenciye gerçek yaşam tecrübeleri sunacak duygu ve düşünceleri aktarmalidir.

- Denetleme: Öğrencinin kendini kontrol etmesini sağlamalı ve eksik yanlarını görmesine olanak tanımalıdır.

- İletişim kurma: Öğrencinin kendini anlatmasını veya karşı tarafa aktarmak istediği bir mesajı anlatmasını sağlamalıdır.

- Davranış geliştirme: Öğrencinin var olan kanılarını değiştirebilmeli ve onu etkilemelidir.

- Bir düşünceyi savunma/bir düşünceye karşı çıkma: Öğrencinin bazı düşünceleri savunmasını, bazı düşünceleri de eleştirmesini sağlamalıdır.

- Estetik yaşam oluşturma: Öğrencinin ilgisini çekecek ve ona zevk verecek şekilde olmalıdır. ${ }^{4}$

Metinde yazar tarafindan okuyucuya verilmek istenen bir mesaj bulunur. Bununla beraber metin içerisinde metin ötesi özellikler de yer alır. Metin ötesi özellikler Diller İçin Avrupa Ortak Öneriler Çerçevesi (Avrupa Konseyi /Modern Diller Bölümü’nde ${ }^{5}$ şu şekilde ifade edilmiştir:

- Resim (fotoğraf, çizim vb.)

- Çizelge, tablo, diyagram vb.

- Dizgisel özellikler (yazı karakteri, punto ve genişlik, alt çizgi, dizgi.)

Yabancı dil öğretiminde kullanılacak metinlerin genel metin özelliklerine bağlı kalmakla birlikte ana dili okurlarına yönelik hazırlanmış metinlerden faklı olarak dil seviyelerine göre hazırlanmış veya uyarlanmış olması dil öğretimini kolaylaştırır.

\subsection{Metin Türleri}

Bir metnin doğru ve kolay bir şekilde anlamlandırılması, metnin türünün doğru belirlenmiş olmasıyla doğrudan ilişkilidir. Metnin yazılma amacı metnin türünü ortaya koyar ve yazar ele alacağı olayı, duyguyu, düşünceyi metnin türünü belirleyerek ifade eder. ${ }^{6}$ Her yazar eserini üretirken farklı bir amaç taşır bu sebeple metnin türü metnin yazılma amacına göre belirlenir. Metinler hedef kitlenin ihtiyaçları göz önünde bulundurularak belirlenir ve genel kabul görmüş kurallara uygun olarak oluşturulur. ${ }^{7}$

Metinlerin öğretim süreci içerisinde yoğun bir şekilde kullanılmaya başlanması metin yapılarına özen gösterilmesini gerektirmektedir. Metinlerin yapılarının karmaşık olması nedeniyle belirli bir tür ve tip tasnifine gitmek zordur. Hatta sınıflanan bir metin yapısı içerisinde

3 Rasih Erkul, Cümle ve Metin Bilgisi (Ankara: Anı, 2004), 80.

4 Alparslan Okur, “Türkçe Ders Kitabı Çözümlemeleri”, Ed. Hakan Ülper, , Türkçe Ders Kitaplarında Metinlerin Türsel Özellikleri içinde, (Ankara: Pegem, 2014), 116.

5 Avrupa Konseyi/Modern Diller Bölümü, Diller İçin Avrupa Ortak Öneriler Çerçevesi Öğrenim, Öğretim ve Dĕ̌gerlendirme, 2013: 91.

6 Erkul, Cümle ve Metin Bilgisi, 178.

7 Muhlise C. Ögeyik, Metinlerarasılık ve Yazın Ë̆itimi (Ankara: Anı, 2008), 11. 
farklı tür metinlerin izleri görülebilmektedir. ${ }^{8}$ Metin tasniflerindeki farklılıklar metinlerle ilgili çalışmalara da yansımaktadır.

Diller İçin Avrupa Ortak Öneriler Çerçevesi’ne göre metinler temelde ikiye ayrılmaktadır. Bunlardan birincisini doğal, yani salt dil öğretimi için değil, bildirişimsel amaçlar için üretilmiş metinler oluştururken ikincisini yabancı dil öğretiminde kullanılmak üzere özel olarak geliştirilmiş metinler oluşturmaktadır. ${ }^{9}$ Metinler, Diller İçin Avrupa Ortak Öneriler Çerçevesi’ne göre bu iki temel ayrımın dışında sözlü ve yazılı olmak üzere 21 türe daha ayrılmaktadır.

Sözlü Metinler:

- Kamu duyuruları ve yönergeler

- Topluluk önünde yapılan konuşmalar, üniversite dersleri, sunumlar, vaazlar

- Geleneksel töreler (törenler gibi)

- Eğlence (dram, şov, okumalar ve şarkılar)

- Spor yorumları (futbol, boks ve at yarışları gibi)

- Haber programları

- Halka açık tartışma ve konuşmalar

- Elemanlar arası ikili konuşma ve sohbetler

- Telefon görüşmesi

- Başvuru görüşmesi

Yazılı Metinler:

- Kitaplar (edebiyat kitapları, teknik kitaplar, edebi dergiler vb. )

- Dergiler

- Kullanım kılavuzları (el işleri ve kendi kendine yap kitapları, yemek tarifi kitapları

- Gazeteler

- Ders kitapları

- Çizgi romanlar

- Broşürler

- El ilanları

- Reklam malzemeleri

- Resmî tabela ve levhalar

- Süpermarket, dükkân ve pazaryerlerinde yer alan tabela ve levhalar

- Ürün etiketleri ve paketleri üzerinde yazılanlar

- Biletler

- Formlar

- Sözlük (tercümeli veya açıklamalı sözlükler)

- Resmî mektuplar (ticari ve mesleki mektuplar), fakslar

- Resmî olmayan mektuplar (özel mektuplar)

8 Ahmet Balcı, Okuma ve Anlama Eğitimi (Ankara: Pegem, 2013), 93.

9 Avrupa Konseyi/Modern Diller Bölümü, Diller İçin Avrupa Ortak Öneriler Çerçevesi Öğrenim, Öğretim ve Değerlendirme, 2013:146. 
- Denemeler, makaleler, alıştırmalar

- Muhtiralar, belgeler, raporlar

- Notlar, mesajlar vb.

- Edebiyat, haber ve genel bilgiler gibi bilgi içeren yazılar. ${ }^{10}$

2017 Türkçe Dersi Öğretim Programı 1-8. Sınıflar 'da ${ }^{11}$ metinler; bilgilendirici metinler, hikâye edici metinler ve şiir olmak üzere üç ana başlık altında toplanmış ve 27 türe ayrılmıştır. Programda hangi metin türlerinin hangi sınıf düzeyinde kullanılıp kullanılmaması gerektiği belirtilmiştir.

Tablo 1. ${ }^{12}$

Sınıf Düzeylerine Göre Metin Türlerinin Dağılımı

\begin{tabular}{|c|c|c|c|c|c|c|c|c|}
\hline TÜRLER & 1 & 2 & 3 & 4 & 5 & 6 & 7 & 8 \\
\hline \multicolumn{9}{|l|}{ BİLGILENDİRİCİ METİNLER } \\
\hline Anı & & + & + & + & + & + & + & + \\
\hline Biyografiler, otobiyografiler & & & & & & & + & + \\
\hline Blok & & & & & & + & + & + \\
\hline Dilekçe & & & & & & & + & + \\
\hline $\begin{array}{l}\text { Efemera ve broşür (liste, diyagram, tablo, grafik, kroki, harita, afiş vb. karma } \\
\text { içerikli metinler) }\end{array}$ & & + & + & + & + & + & + & + \\
\hline e-posta & & & + & + & + & + & + & + \\
\hline Günlük & & + & + & + & & & & \\
\hline Haber metni, reklam & & + & + & + & + & + & + & + \\
\hline Kartpostal & & + & + & + & & & & \\
\hline Kılavuzlar (kullanım kılavuzları, tarifname, talimatnameler vb.) & & + & + & + & + & + & + & + \\
\hline Makale/fikra/söyleşi/deneme & & & & & + & + & + & + \\
\hline Mektup & & & & & + & + & + & + \\
\hline Özlü sözler (atasözü, deyim, duvar yazıları, döviz vb.) & + & + & + & + & & & & \\
\hline Özlü sözler (vecize, atasözü, deyim, aforizma, duvar yazıları, motto, döviz vb.) & & & & & + & + & + & + \\
\hline Sosyal medya mesajları & & & & + & + & + & + & + \\
\hline \multicolumn{9}{|l|}{ HİKÂYE EDİCİ METİNLER } \\
\hline Çizgi roman & + & + & + & + & + & + & + & + \\
\hline Fabl & + & + & + & + & + & + & + & + \\
\hline Hikâye & + & + & + & + & + & + & + & + \\
\hline Karikatür & + & + & + & + & + & + & + & + \\
\hline Masal/efsane/destan & + & + & + & + & + & + & + & + \\
\hline Mizahi fikra & + & + & + & + & + & + & + & + \\
\hline Roman & & & & + & + & + & + & + \\
\hline Tiyatro & + & + & + & + & + & + & + & + \\
\hline ŞIIIR & + & + & + & + & + & + & + & + \\
\hline Mâni/ninni & + & + & + & + & & & & \\
\hline Şark1/türkü & + & + & + & + & + & + & + & + \\
\hline Şiir & + & + & + & + & + & + & + & + \\
\hline Tekerleme/sayışmaca/bilmece & + & + & + & + & & & & \\
\hline
\end{tabular}

10 Avrupa Konseyi/Modern Diller Bölümü, Diller İçin Avrupa Ortak Öneriler Çerçevesi Öğrenim, Öğretim ve Değerlendirme, 2013, 96-97.

11 1.-8. Türkçe dersi öğretim programı, Millî Eğitim Bakanlığı (Ankara, 2017), 20.

12 1.-8. Türkçe dersi ögretim programı, Millî Eğitim Bakanlığ (Ankara, 2017.) 
Günay ${ }^{13}$ metinlerin sınıflandırılmasını ton, tip ve tür olarak 3 başlık altında ele almıştır. Metnin tonu; yazarın okuyucuda üzüntü, heyecan, sevinç, coşku gibi ruhsal etkiler oluşturmak için kullandığı özelliklerdir. Metnin genel özelliğini, daha genel metin ulamlarını belirten metnin tipi; yazarın niyetine (metnin işlevine) ve yazarın metni düzenleyişine bağlıdır. Günay’a göre insanların günlük yaşam içerisinde karşılaşabileceği metinler şu şekilde sıralanabilir: ${ }^{14}$

- Anlatı türü metinler: Roman, kısa öykü, anı, yaşanılanlarla ilgili belgesel anlatımlar.

- Şiirsel metinler: Mâni, koşuk, manzume, düzyazı şiir, serbest şiir, şarkı, destan.

- Söyleşimsel metinler: Tiyatro anlatımı, fotoroman, çizgi film, altyazılı filmler.

- Basın metinleri: Röportaj, bildirge, görüşme, haber yorumu, köşe yazısı, gazete, dergi gibi yazılı basın tarafından yapılan açıklamalar.

- Özel bilgilendirici metinler: Bilimsel dergi makaleleri, bilimsel kitaplar.

- İşlevsel metinler: Kullanma kılavuzu, uyarıcı notlar, resmî matbu belgeler.

- Öğretici metinler: Ders kitapları, ders fotokopileri.

- Çözümleme ile ilgili metinler: İncelemeler, denemeler, araştırma metinleri.

- Mesleki metinler: Rapor, tanıtım yazısı, mahkeme tutanağı, polis kaydı, bilgilendirici yazılar, kurum içi, yazışmalar, imza sirküleri, bilgilendirici notlar.

- Haberleşme metinleri: Aile bireyleri arasındaki mektuplar, resmî yazışmalar, arkadaş mektupları, meslekî yazışmalar.

- Uyarıcı yazılar, panolar, pankartlar.

- Afişler, el ilanları.

- Bir metin grubu olarak belli örnekçelere, uzlaşma ve genel kabul görmüş biçemlere uyan metinleri belirten metin türü Günay tarafından genel hatlarıyla şu şekilde tablolaştırılmıştır: ${ }^{15}$

13 Doğan Günay, Metin Bilgisi (İstanbul: Papatya, 2013), 219-391.

14 Günay, Metin Bilgisi, 220-221.

15 Günay, Metin bilgisi, 393-394. 
Tablo 2.16

Günay’a Göre Metin Türlerinin Tasnifi

\begin{tabular}{|c|c|c|c|}
\hline Metin Türü & $\begin{array}{l}\text { Bu Türün Olabileceği } \\
\text { Metin Tipleri }\end{array}$ & $\begin{array}{l}\text { Bu Türdeki Baskın Dilin } \\
\text { İşlevi }\end{array}$ & Tür Örnekleri \\
\hline Aytamlıkla ilgili & Kanıtlayıcı, sözbilimsel & $\begin{array}{l}\text { Anlatımsal, çağrı, sanat } \\
\text { işlevleri }\end{array}$ & $\begin{array}{l}\text { Övgü, ağıt söylevi, davet, } \\
\text { sorgulama }\end{array}$ \\
\hline Destans1 & $\begin{array}{l}\text { Şiirsel, anlatısal ve } \\
\text { betimleyici metin tipi }\end{array}$ & $\begin{array}{l}\text { Sanat işlevi ve gönderge } \\
\text { işlevi }\end{array}$ & $\begin{array}{l}\text { Destan, kahramanlık destanı, } \\
\text { roman, tarihsel anlatılar vb. }\end{array}$ \\
\hline Dramatik & Söyleşimsel, Sözbilimsel & Anlatımsal ve çağrı işlevleri & $\begin{array}{l}\text { Dram, romantik dramlar, } \\
\text { günümüzdeki dram örnekleri }\end{array}$ \\
\hline Güldürücü & Anlatısal, söyleşimsel & $\begin{array}{l}\text { Anlatımsal, çağrı, sanat } \\
\text { işlevleri }\end{array}$ & $\begin{array}{l}\text { Töre güldürüleri, dolantı } \\
\text { güldürüleri, karakter } \\
\text { güldürüleri, benzek, gülünç } \\
\text { kahraman romanları, } \\
\text { renklemeli romanlar, skeç, } \\
\text { parodi, din adamlarını ele } \\
\text { alan güldürüler, kısa oyunlar, }\end{array}$ \\
\hline İçsel & $\begin{array}{l}\text { Sözbilimsel, betimleyici, } \\
\text { anlatısal }\end{array}$ & Anlatımsallık işlevi & $\begin{array}{l}\text { İçsel şiirler, düşlemler, } \\
\text { şarkılar }\end{array}$ \\
\hline Mektup & $\begin{array}{l}\text { Anlatısal betimleyici, } \\
\text { kanıtlayıcı }\end{array}$ & Anlatımsal ve çağrı işlevi & $\begin{array}{l}\text { Mektup roman, açık mektup, } \\
\text { koşuklu mektup }\end{array}$ \\
\hline $\begin{array}{l}\text { Olağanüstü ve } \\
\text { düşlemsel }\end{array}$ & $\begin{array}{l}\text { Anlatısal, betimleyici, } \\
\text { sözbilimsel, söyleşimsel }\end{array}$ & Çağrı ve sanat işlevleri & $\begin{array}{l}\text { Peri masalı, düşlemsel roman, } \\
\text { bilim kurgu anlatıları }\end{array}$ \\
\hline Öğretici & $\begin{array}{l}\text { Açıllayıcı, kanıtlayıcı, } \\
\text { anlatısal, betimleyici, } \\
\text { sözbilimsel }\end{array}$ & $\begin{array}{l}\text { Gönderge, çağrı ve } \\
\text { anlatımsallık işlevleri }\end{array}$ & $\begin{array}{l}\text { Deneme, tarih yazarlığı, } \\
\text { özyaşamöyküsü, yazınsal bir } \\
\text { bildirge, sağsöz, özlü söz, } \\
\text { ulusöz, atalar sözü, öykünce, } \\
\text { öğütlük, betimce, yazın } \\
\text { eleştirisi }\end{array}$ \\
\hline Öz yaşam öyküsel & Anlatısal, betimleyici & $\begin{array}{l}\text { Anlatımsallık ve çağrı } \\
\text { işlevleri }\end{array}$ & $\begin{array}{l}\text { İtiraf, anı, özbetimce, günce, } \\
\text { günlük }\end{array}$ \\
\hline Polemik & Kanıtlayıc1, sözbilimsel & $\begin{array}{l}\text { Çağrı, anlatımsal, sanat } \\
\text { işlevleri }\end{array}$ & Taşlama, iğneleme, yergilik \\
\hline Romanesk & Anlatısal, betimleyici & Sanat işlevi & Masal, kısa öykü, roman \\
\hline Ağlatısal & Söyleşimsel & $\begin{array}{l}\text { Anlatımsal, çağrı, sanat } \\
\text { işlevleri }\end{array}$ & $\begin{array}{l}\text { Gülünç ağlatılar, ağlatısal } \\
\text { anlatımlar }\end{array}$ \\
\hline
\end{tabular}

Metinleri kullanıldıkları iletişimsel amaç ve sosyal bağlam paralelinde belirli yapısal ve söylemsel özellikler çerçevesinde sinıflandıran Dilidüzgün ise metin türlerini şu şekilde tablolaştırmışıtır: ${ }^{17}$ 
Tablo 3. ${ }^{18}$

Dilidüzgün'e Göre Metin Türlerinin Tasnifi

\begin{tabular}{|c|c|c|c|c|c|}
\hline \multicolumn{6}{|c|}{ Yapı ve işlevleri bağlamında metin türleri } \\
\hline \multirow{2}{*}{ Betimsel metin } & \multirow{2}{*}{ Anlatısal metin } & \multicolumn{2}{|c|}{ Açıklayıcı metin } & \multirow{2}{*}{$\begin{array}{l}\text { Kanitlayıcı } \\
\text { metin }\end{array}$} & \multirow{2}{*}{ Çağrı işlevli metin } \\
\hline & & Bilgi İleten & Öğretici & & \\
\hline Turist rehberi & Roman & Resmî belgeler & Bilimsel & Açık oturum & Duyurular \\
\hline Hava durumu & Öykü & Tanitimlar & yazilar & Panel & Duvar yazıları \\
\hline raporu & Masal/Destan & Haber metinleri & Resmî belgeler & Münazara & Talimatlar \\
\hline Reçete & Şiir & İş mektupları & Ders kitapları & Eleştiri yazıları & Reklamlar \\
\hline Kilavuz & F1kra & Başvuru formları & Dinsel & Deneme & Propaganda \\
\hline Düșünce yazısı & Fabl & Özgeçmiş & metinler/vaaz & Makale & Döviz \\
\hline Ansiklopedi & Bilim-kurgu & F1kra & Eğitim & F1kra & Pankart \\
\hline maddesi & Mizah & Deneme & kitapları & Röportaj & Çağrılar \\
\hline Emlak ve iş & Sinema & Eleştiri & Alan kitapları & Düşünce ve & Broşür \\
\hline ilanları & Çizgi filmler & Gezi yazıları & Ek materyaller & felsefe yazıları & İlan \\
\hline Anlaşmalar & Maç anlatımı & Röportajlar & Tahtaya & Raporlar & Davetiye \\
\hline Dilekçeler & Günlük & Ansiklopedi & yazılan bilgiler & İş mektupları & Afiş \\
\hline Kataloglar & Tarihçe & maddeleri & Popüler- & Bilimsel yazılar & Hitaplar \\
\hline Sözlükler & Haber metinleri & Dergi yazıları & bilimsel & Bilimsel & Programlar \\
\hline Bulmacalar & Raporlar & El ilanları & metinler & değerlendirme/ & Sloganlar \\
\hline Reklamlar & Yaşam öyküsü & Raporlar & Hobi kitapları & yorum & Konum \\
\hline Tarih kitapları & Hazırlanmış & Bilimsel metinler & Yemek tarifleri & Magazin & "Nerdesiniz?" \\
\hline Savunma & konuşma & Felsefi metinler & & Kurum içi & metinleri \\
\hline tutanakları & Başyazılar & Otobüs tarifeleri & & bilgilendirici/ & Yemek tarifleri \\
\hline Eşya döküm & Kişisel mektup & Sözlük maddeleri & & yönlendirici & Kullanma kılavuzları \\
\hline listeleri & Tanıklık bilgileri & Programlar & & yazılar & Yönetmelik \\
\hline Bilim/teknik & Belgesel & Duyurular & & & Yönerge \\
\hline inceleme & E-posta & Menüler & & & Dinsel metinler \\
\hline yazıları & Telgraf & Kişisel ve iş & & & Politik konuşmalar \\
\hline Roman özetleri & & mektupları & & & Karar metinleri \\
\hline Reklam & & Garanti belgesi & & & Planlama metinleri \\
\hline metinleri & & $\begin{array}{l}\text { Yüz yüze ve } \\
\text { telefonla konusma }\end{array}$ & & & $\begin{array}{l}\text { Kişisel ve iş } \\
\text { mektupları }\end{array}$ \\
\hline
\end{tabular}

Cemiloğlu, Bloom Taksonomisi’nden hareketle eğitim bilimlerinde üç öğrenme alanı olarak bilinen bilişsel, duyuşsal ve psikomotor alanlardan hareketle metin türlerini düşünceye dayalı, duyguya dayalı ve olaya dayalı türler olarak üç farklı gruba ayırmıştır. Bu üç ana başlık altında ele alınan türler şu şekilde tasnif edilmiştir:

Düşünceye dayalı türler: Makale, deneme, söyleşi, fikra, eleştiri, inceleme

Duyguya dayalı türler: Şiir

Olaya dayalı türler: Hikâye, roman, tiyatro, masal, efsane, destan, fabl, anı, gezi yazısı. ${ }^{19}$

\subsection{Yabancı Dil Olarak Türkçe Öğretiminde Metin Türlerinin Sınıflandırılması}

Alan yazınında karşılaşılan metin türlerine ait sınıflandırmaların tamamı, teorisyenler ve araştırmacılar tarafından yapılan çalışmaların içeriğine uygun olarak uyarlanmıştır. ${ }^{20}$ Her bir

18 Dilidüzgün, Metindilbilim ve Türkçe öğretimi.

19 Mustafa Cemiloğlu, İlköğretim Okullarında Türkçe Öğretimi, (Bursa: Alfa Aktüel, 2015), 29-60.

20 Cihat, Burak Korkmaz, "Metin Sınıflandırması Bağlamında Yabancı Dil Olarak Türkçenin Öğretiminde Kullanılan Dinleme Metinleri”, Türkiyat Mecmuası, 29/1, (2019), 105. 
metin tasnifi kendi içerisinde tutarlı ve anlamlı olmakla beraber bakış açılarındaki farklılıklar sebebiyle birçok metin türü tasnifi ortaya çıkmıştır. Araştırmacılar metinleri kendi bakış açılarından ele almışlar böylelikle edebiyat bilimi, dil bilim, eğitim bilimi ve programları vb. alanlarına hitap eden metin türü tasnifleri oluşturmuşlardır. Ancak dil öğretimi açısından metin ve metin türü kavramları söz konusu tasniflerden bazı farklılıklar taşımaktadır. Çünkü dil öğretiminde kullanılacak metin bir materyal niteliğindedir. Böylelikle amaç ve kazanımları gerçekleştirebilecek her metnin okuma ve dinleme metni olarak kabul edilmesi mümkündür.

İster ana dili eğitiminde ister Türkçenin yabancı dil olarak öğretiminde kullanılacak okuma ve dinleme metinleri en başta öğretim aracı ve materyali olarak görülmelidir. Türkçe öğretimi sürecinde basit düzeydeki metinlerden derin anlamlar içeren edebî metinlere kadar her metnin kullanım alanı vardır. Örneğin, yabancılara Türkçe öğretiminde lokantada sipariş veren bir müşteri ile garson arasındaki bir metin yahut ana dili eğitiminde bir gazetedeki haber yazısı okuma metni özelliğindedir. Aynı şekilde mecazlar ve sanatlı ifadeler içeren bir şiir metni de ders kitabındaki bilgi aktaran metin de okuma-dinleme metni özelliği taşımaktadır. Yani dil öğretimi açısından okunabilecek ya da dinlenebilecek her anlam unsuru metin niteliği taşımaktadır. Bu açıdan bakıldığında yukarıda yer verilen tasniflerin, dil öğretimi için kullanılan metinleri tasnif etmede yer yer eksiklikler içerdiği görülmektedir. Söz konusu eksiklikleri de göz önüne alarak dil öğretimi bakış açısı ile yeni bir metin türü tasnifi önerisi ortaya koymak mümkündür.

Yabanc1 dil öğretiminde metinlerin tasnifini yaparken metinleri oluşturulma amacına göre metinler ve işlevlerine göre metinler olarak ikiye ayırmak mümkündür. Oluşturulma amacına göre metinler doğrudan dil öğretme amacına yönelik hazırlanmış kurgu metinler ve ana dili kullanıcılarının günlük hayat kullanımlarına yönelik hazırlanmış ve dolaylı olarak yabancı dil öğretiminde kullanılan özgün metinler olarak ikiye ayrılabilir. İşlevlerine göre metinler ise yazılış amacı ve dil kullanımı açısından ele alınarak kullanım işlevli metinler ve edebî metinler olarak iki ana başlık altında toplanabilir.

Oluşturulma amacına göre metinler arasında yer alan özgün metinler de kendi içerisinde gündelik metinler ve yazınsal metinler olmak üzere ikiye ayrılabilir. Gündelik metinler herhangi bir estetik kaygı güdülmeksizin hazırlanmış ve hedef kitlesi ana dili okurları olan menü, bilet, afiş, garanti belgesi, duvar yazısı vb. metinlerdir. Yazınsal metinler ise estetik bir kaygı ile kaleme alınan ve hedef kitlesi ana dili okurları olan roman, hikâye, masal, efsane vb. metinlerdir.

Oluşturulma amacına göre metinler şu şekilde sınıflandırılabilir:

\section{Tablo 4}

Oluşturulma Amacına Göre Metin Türleri

Oluşturulma Amacina Göre Metinler

\begin{tabular}{ll}
\hline Kurgu Metinler & Özgün (Otantik) Metinler \\
\hline & 1- Gündelik metinler \\
& 2- Yazınsal metinler \\
\hline
\end{tabular}


İşlevlerine göre metinlerden kullanım işlevli metinler; yazılış amacı, dil kullanımı vb. bakımından edebî bir özellik taşımayan, herhangi bir estetik kaygı güdülmeksizin günlük hayat içerisinde karşılaşılabilecek her türlü okuma materyalini karşılamaktadır. Kullanım işlevli metinler kendi içerisinde resmî yazılar, öğretici metinler ve iletişimsel metinler olmak üzere 3 başlık altında toplanabilir.

Edebî metinler yazılış amacı ve dil kullanımı itibarıyla estetik bir kaygı ile kaleme alınmış metinlerdir. Edebî metinler de kendi içerisinde bilgi verici metinler, anlatmaya/göstermeye dayalı metinler ve nazım olmak üzere 3 başlıkta toplanabilir.

Tablo 5.

İşlevlerine Göre Metin Türleri

Kullanım işlevli metinler

Resmî yazılar Öğretici metinler

$\begin{array}{ll} & \text { Edebî metinler } \\ \begin{array}{l}\text { İletişimsel } \\ \text { metinler }\end{array} & \text { Öğretici } \\ \text { metinler }\end{array}$

Anlatmaya/ Nazım Herhangi bir

Göstermeye sinıflandırma

dayalı

metinler içerisinde yer verilemeyen ve birden fazla türün özelliğini taşıyan metinler

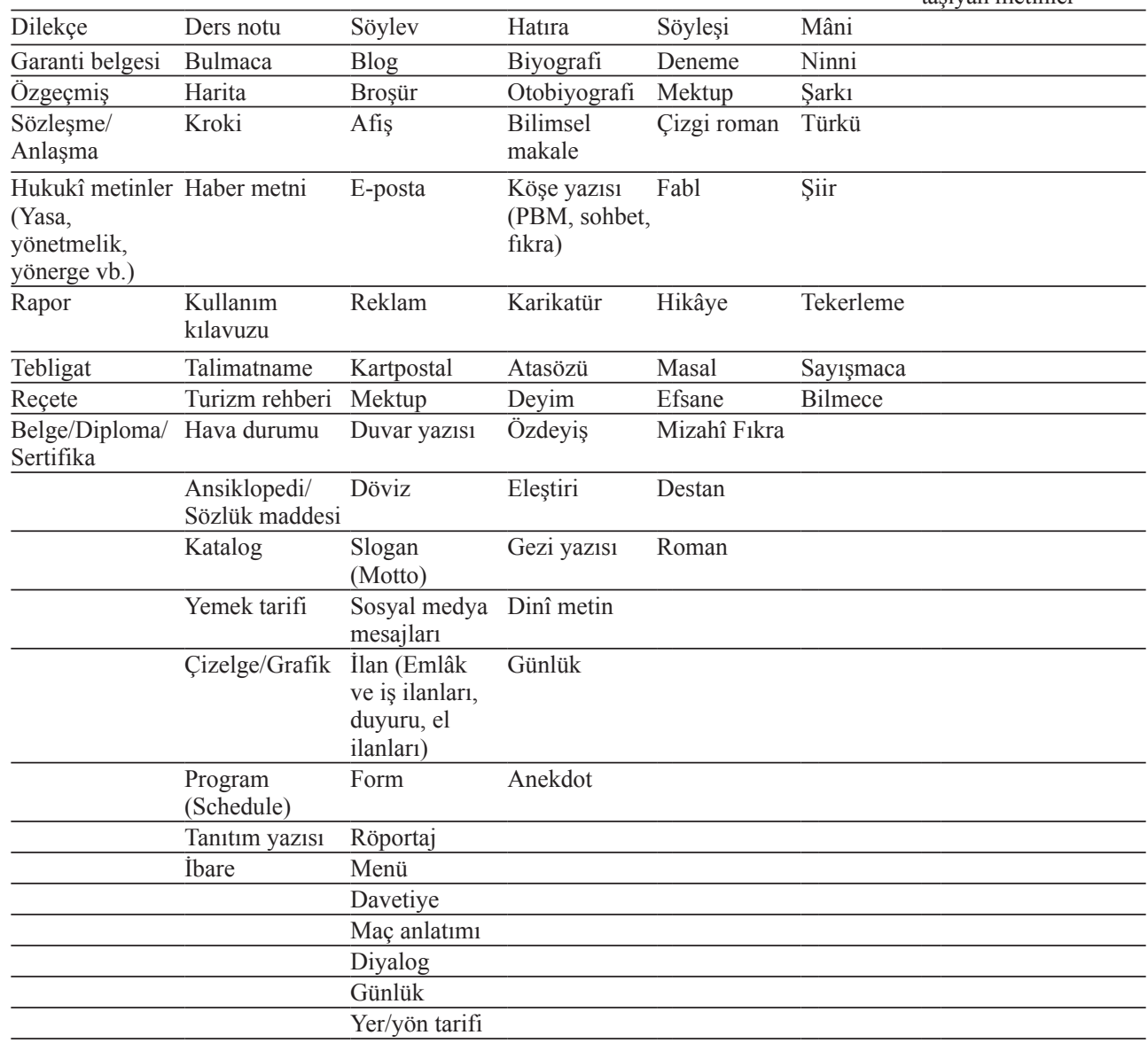


Metin türlerinin tasnifinde çalışmanın özelliğine bağlı olarak her metin bir sınıflandırmanın içerisinde ele alınmaktadır. Ancak bazı metinler bir veya en fazla iki cümleden oluşturularak bir beceriyi geliştirmeye veya özellikle dil bilgisi temelli yeni bir kavramı öğretmeye yönelik olarak kullanılmaktadır. Bu tür yapılar dil öğretimi üzerine oluşturulan hemen hemen her kaynakta bulunmaktadır. İlgili yapıların sınıflandırılması ile alakalı yapılan çalışmalar sonucunda bir kavram olarak ibare bu çalışmada bir tür olarak yer almaktadır.

İbare kavramı ile ilgili alanyazında yapılan taramalar sonucunda ibare kavramına eski Türk edebiyatı bilim dalının bir çalışma konusu olarak metin tahlillerinde rastlanmaktadır. Çetişli, metni; "Herhangi bir konu veya olayı anlatmakla görevli kelimeler, ibareler, deyimler, cümlecikler, cümleler ve paragraflardan oluşan söz bütünü’’21 şeklinde ifade ederken ibareyi de bir metin olarak değerlendirmektedir.

Bu nedenle ibareye metin türleri sınıflandırmasında kullanım işlevli metin türleri başlığ altında yer verilmesi uygun görülmektedir. Ancak metin türleri ölçütleri tanımlamalarının tamamına uymayan veya birden fazla birbirine benzeyen tür ölçütlerine sahip olan metinler olabilmektedir. Bu bağlamda bakıldığında ise birden fazla metin türünün farklı özelliklerini taşıyan ve herhangi bir sınıflandırma içerisinde yer verilemeyen metin türleri çalışma içerisinde "diğer" başlı̆̆ı altında sınıflandırılmıştır.

\section{3. Çalıșmanın Amacı}

Yabancı dil olarak Türkçenin öğretiminde ortak bir programın bulunmaması her kurumun farklı uygulamalar ile öğretim yapmasına sebep olmaktadır. Uygulanan öğretim programına daha çok kurumun kullanmakta olduğu öğretim seti yön vermektedir. Öğretim setlerinin niteliği öğretimin kalitesini de belirlemektedir. Bu bakımdan Türkçe öğretim merkezleri tarafından kullanılan öğretim setleri Türkçe öğretimi açısından büyük önem arz etmektedir. Türkçe öğretim setlerinin ana yapısını ders kitapları oluşturmaktadır. Ders kitapları öğretimin amaçlarını gerçekleştirmek için öğrencilerin öğrenme yaşantılarına kaynaklık etmekte ve çoğu zaman öğretim sürecinde kullanılan tek materyal olarak karşımıza çıkmaktadır. ${ }^{22}$ Ders kitapları içerisinde okuma becerisini geliştirmeye yönelik etkinlikler yoğun bir şekilde kullanılmaktadır. Ders kitaplarında yer alan okuma etkinlikleri diğer dil becerileri ile de sıkı bir ilişki içerisinde olup diğer dil becerilerinin gelişimi açısından büyük önem ifade etmektedir. Bu bakımdan okuma etkinlikleri Türkçenin yabancı dil olarak öğretiminde büyük öneme sahiptir. Okuma etkinliklerinin ana omurgasını oluşturan okuma metinlerinin dil öğrenicilerinin seviyesine ve öğrenmekte oldukları konuya göre çeşitlilik sunması beklenir.

Bu doğrultuda çalışmanın amaç cümlesini "Türkçenin yabancı dil olarak öğretiminde kullanılan ders kitaplarındaki metin türlerinin dağılımı nasıldır?” sorusu oluşturmaktadır. Çalışmanın alt amaçları ise şu şekildedir:

21 İsmail Çetişli, Edebiyat Sanatı ve Bilimi (Ankara: Akçă̆, 2011), 322.

22 Funda Toprak, "Yabancılara Türkçe Öğretimi Kitaplarındaki Okuma Parçaları ve Diyaloglar Üzerine Bir Değerlendirme", Türkiyat Araştırmaları Dergisi, 29, (2011), 32. 
1. Türkçenin yabancı dil olarak öğretiminde metin türü tasnifi nasıl olmalıdır?

2. YİTÖS ders kitaplarında yer alan okuma metin türlerinin çeşitliliği nasıldır?

3. İTÖS ders kitaplarında yer alan okuma metin türlerinin çeşitliliği nasıldır?

\section{Yöntem}

\subsection{Araştırmanın Modeli}

Yabancı dil olarak Türkçe Öğretim setlerindeki okuma metinlerinin içerdiği özellikleri ve birbirinden farkını ortaya koymayı amaçlayan bu çalışmanın araştırma modeli nitel olarak belirlenmiştir. Çalışmada verilerin tespiti için doküman analizi tekniğine başvurulmuştur.

\subsection{Evren ve Örneklem}

Çalışmanın evrenini yabancı dil olarak Türkçenin öğretiminde kullanılan ders kitapları oluşturmaktadır. Çalışmanın örneklemini ise Yunus Emre Enstitüsü tarafından hazırlanmış Yedi İklim Türkçe Öğretim Seti ve İstanbul Üniversitesi öğretim elemanlarının tecrübeleriyle oluşturulmuş İstanbul Yabancılar İçin Türkçe Öğretim Seti’ne ait A1, A2, B1, B2 ve C1 ders kitaplarında yer alan okuma başlığı altındaki okuma metinleri oluşturmaktadır.

\subsection{Verilerin Toplanması ve Çözümlenmesi}

Yedi İklim Türkçe Öğretim Seti ve İstanbul Yabancılar İçin Türkçe Öğretim Seti’nde yer alan oluşturulma amacına göre metin türleri ve işlevlerine göre metin türleri doküman analizi tekniği kullanılarak tespit edilmiştir. Tespit edilen veriler sayısal bakımdan ve yüzdelik değer bakımından ele alınmıştır.

\section{Bulgular}

\subsection{Oluşturulma Amacına Göre Metin Türlerine İlişkin Bulgular}

Metinler, oluşturulma amacına göre kurgu ve özgün olmak üzere iki grupta değerlendirilmektedir. Metinlerin oluşturulma amacına göre değerlendirilmesinde bir metnin özgün metin olarak kabul edilebilmesi için dikkat edilen hususlar şunlardır:

1- Yazınsal özgün metinlerde kaynak gösterilip gösterilmediğine bakılmıştır. Ancak yazınsal özgün metinler içerisinde yer alan efsane, masal, mizahi fikra, mâni gibi anonim türler kaynak gösterilmesine bakılmaksızın özgün metinler içerisinde değerlendirilmiştir.

2- Gündelik özgün metinler kaynak gösterilip gösterilmemesine bakılmaksızın özgün metin olarak kabul edilmiştir.

Örneğin, gündelik özgün metinlerden YİTÖS B1 ders kitab1 85. sayfada yer alan “Altınkanat Buzdolabı İçin Garanti Belgesi” adlı okuma metni herhangi bir kaynak gösterilmemesine ve gerçekte böyle bir marka bulunmamasına rağmen orijinal bir garanti belgesi formatında üretilmiş bir metin olması sebebiyle özgün metin olarak değerlendirilmiştir. Yazınsal özgün metinlerden YİTÖS B1 ders kitabında 155. sayfada yer alan ve anonim bir tür olan "mâni" 
özgün metin olarak değerlendirilmiştir.

Oluşturulma amacına göre metin türlerine ait bulgularla ilgili veriler seviyelere ve ünitelere göre şu şekildedir:

Tablo 6.

Oluşturulma Amacına Göre Okuma Metin Türlerinin Dağılımı

\begin{tabular}{|c|c|c|c|c|c|c|c|c|c|c|c|c|c|c|c|c|c|}
\hline \multicolumn{18}{|l|}{$\mathrm{A} 1$} \\
\hline & \multicolumn{2}{|c|}{ 1. Ünite } & \multicolumn{2}{|c|}{ 2. Ünite } & \multicolumn{2}{|c|}{ 3. Ünite } & \multicolumn{2}{|c|}{ 4. Ünite } & \multicolumn{2}{|c|}{ 5. Ünite } & \multicolumn{2}{|c|}{ 6. Ünite } & 7. Ünite & \multicolumn{2}{|c|}{ 8. Ünite } & \multicolumn{2}{|c|}{ Toplam } \\
\hline & $\overline{\mathrm{K}}$ & Ö & $\mathrm{K}$ & $\ddot{O}$ & $\mathrm{~K}$ & $\ddot{O}$ & $\mathrm{~K}$ & Ö & K & Ö & K & $\ddot{O}$ & $\mathrm{~K} \quad \ddot{\mathrm{O}}$ & K & Ö & K & Ö \\
\hline YİTÖS & 15 & & 9 & & 12 & & 13 & 1 & 15 & & 7 & & 6 & 9 & 1 & 86 & 2 \\
\hline İTÖS & 2 & & 4 & & 4 & & 4 & & 4 & & 4 & & & & & 22 & \\
\hline \multicolumn{18}{|l|}{ A2 } \\
\hline & \multicolumn{2}{|c|}{ 1. Ünite } & \multicolumn{2}{|c|}{ 2. Ünite } & \multicolumn{2}{|c|}{ 3. Ünite } & \multicolumn{2}{|c|}{ 4. Ünite } & \multicolumn{2}{|c|}{ 5. Ünite } & \multicolumn{2}{|c|}{ 6. Ünite } & 7. Ünite & \multicolumn{2}{|c|}{ 8. Ünite } & \multicolumn{2}{|c|}{ Toplam } \\
\hline & $\overline{\mathrm{K}}$ & $\ddot{O}$ & $\mathrm{~K}$ & Ö & $\mathrm{K}$ & Ö & $\mathrm{K}$ & $\ddot{O}$ & $\mathrm{~K}$ & Ö & $\mathrm{K}$ & Ö & $\mathrm{K} \quad \ddot{\mathrm{O}}$ & $\mathrm{K}$ & Ö & $\mathrm{K}$ & Ö \\
\hline YİTÖS & 11 & 2 & 10 & 1 & 9 & & 5 & 4 & 8 & & 7 & & 10 & 6 & 1 & 66 & 8 \\
\hline İTÖS & 3 & 1 & 3 & 1 & 4 & & 1 & 3 & 3 & 1 & 4 & & & & & 18 & 6 \\
\hline \multicolumn{18}{|l|}{ B1 } \\
\hline & \multicolumn{2}{|c|}{ 1. Ünite } & \multicolumn{2}{|c|}{ 2. Ünite } & \multicolumn{2}{|c|}{ 3. Ünite } & \multicolumn{2}{|c|}{ 4. Ünite } & 5.1 & nite & 6. I & nite & 7. Ünite & 8. 1 & nite & Top & am \\
\hline & $\overline{\mathrm{K}}$ & Ö & $\mathrm{K}$ & Ö & $\mathrm{K}$ & Ö & $\mathrm{K}$ & Ö & $\mathrm{K}$ & Ö & $\mathrm{K}$ & Ö & $\mathrm{K} \quad \ddot{\mathrm{O}}$ & $\mathrm{K}$ & Ö & $\mathrm{K}$ & Ö \\
\hline YİTÖS & 9 & & 9 & 3 & 12 & 3 & 12 & 5 & 6 & & 8 & 2 & 7 & 3 & 5 & 66 & 18 \\
\hline İTÖS & 3 & 1 & 1 & 3 & & 4 & 2 & 2 & 3 & 1 & 3 & 1 & & & & 12 & 12 \\
\hline B2 & & & & & & & & & & & & & & & & & \\
\hline & 1. I & nite & 2.1 & nite & 3. & nite & 4. $\mathrm{I}$ & nite & 5.1 & nite & $6 . \dot{1}$ & nite & 7. Ünite & 8. & nite & Top & $\mathrm{am}$ \\
\hline & $\mathrm{K}$ & Ö & $\mathrm{K}$ & Ö & $\mathrm{K}$ & Ö & $\mathrm{K}$ & Ö & $\mathrm{K}$ & Ö & $\mathrm{K}$ & Ö & $\mathrm{K} \quad$ Ö & $\mathrm{K}$ & Ö & $\mathrm{K}$ & Ö \\
\hline YİTÖS & 13 & 1 & 5 & 2 & 8 & 3 & 3 & 2 & 4 & 3 & 8 & & 6 & 4 & 1 & 51 & 12 \\
\hline İTÖS & 2 & 2 & 3 & 1 & 2 & 2 & 2 & 1 & 1 & 3 & 3 & 1 & & & & 13 & 10 \\
\hline $\mathrm{C} 1$ & & & & & & & & & & & & & & & & & \\
\hline & $1 . \dot{I}$ & nite & 2.1 & nite & 3. U & nite & 4. I & nite & 5.1 & iite & $6 . \dot{1}$ & nite & 7. Ünite & 8. I & nite & Top & $\mathrm{am}$ \\
\hline & $\mathrm{K}$ & Ö & $\mathrm{K}$ & Ö & $\mathrm{K}$ & Ö & $\mathrm{K}$ & Ö & $\mathrm{K}$ & Ö & $\mathrm{K}$ & Ö & $\mathrm{K} \quad \ddot{\mathrm{O}}$ & $\mathrm{K}$ & Ö & $\mathrm{K}$ & Ö \\
\hline YİTÖS & 6 & 2 & 5 & 4 & 4 & 5 & 8 & & 7 & & 3 & 3 & 11 & 1 & 5 & 37 & 30 \\
\hline İTÖS & 3 & 4 & 4 & 3 & 2 & 4 & 3 & 3 & 4 & 2 & 4 & 2 & & & & 20 & 18 \\
\hline TOPLAI & & & & & & & & & & & & & & & & & \\
\hline & 1. $\mathrm{I}$ & nite & 2.1 & nite & 3. & nite & 4. $\dot{\mathrm{L}}$ & nite & $5 . \mathrm{i}$ & nite & $6 . \dot{1}$ & nite & 7. Ünite & $8 . \dot{U}$ & nite & Top & $\mathrm{am}$ \\
\hline & $\mathrm{K}$ & Ö & $\mathrm{K}$ & Ö & $\mathrm{K}$ & Ö & $\mathrm{K}$ & Ö & $\mathrm{K}$ & Ö & $\mathrm{K}$ & Ö & $\mathrm{K} \quad$ Ö & $\mathrm{K}$ & Ö & $\mathrm{K}$ & Ö \\
\hline YİTÖS & 54 & 5 & 38 & 10 & 45 & 11 & 41 & 12 & 40 & 3 & 33 & 5 & $32 \quad 11$ & 23 & 13 & 306 & 70 \\
\hline İTÖS & 13 & 8 & 15 & 8 & 12 & 10 & 12 & 9 & 15 & 7 & 18 & 4 & & & & 85 & 46 \\
\hline
\end{tabular}


5.1.1. Oluşturulma Amacına Göre Metin Türlerine Ait Seviye Odaklı Sayısal ve Yüzdelik Dağılımlarına İlişkin Bulgular

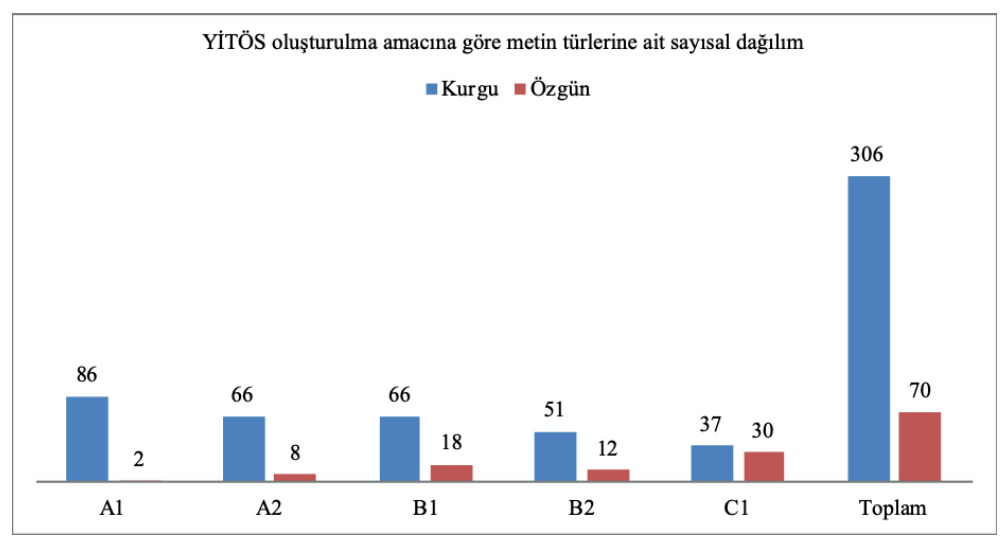

Şekil 1. YITTÖS oluşturulma amacına göre metin türlerine ait sayısal dağılım

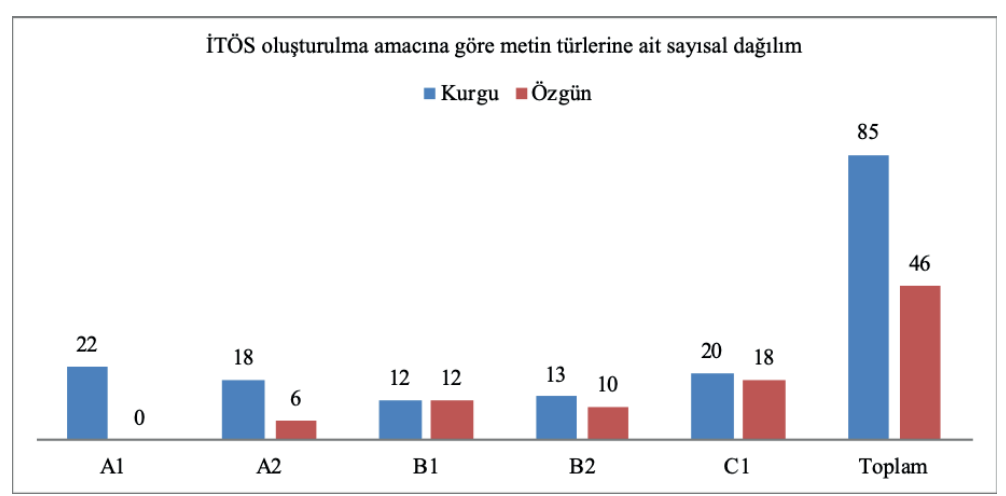

Şekil 2. İTÖS oluşturulma amacına göre metin türlerine ait sayısal dağılım

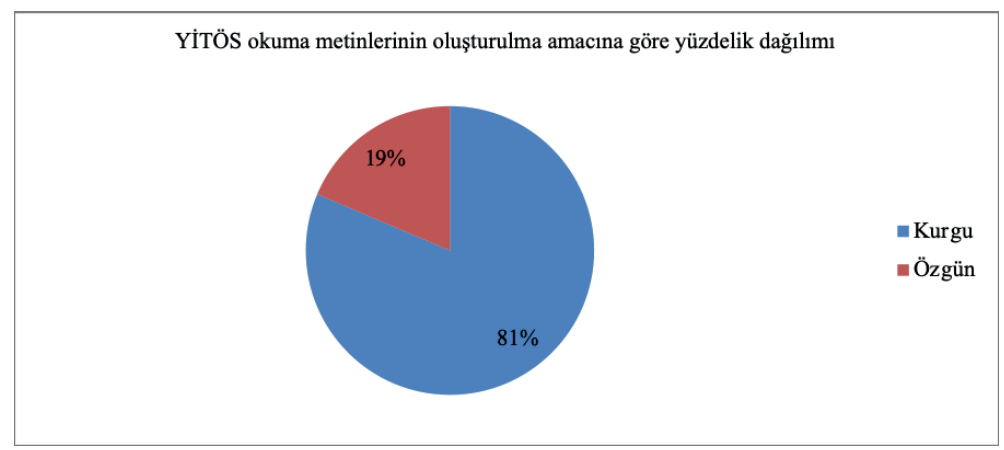

Şekil 3. YITTÖS okuma metinlerinin oluşturulma amacına göre yüzdelik dă̆ılımı 


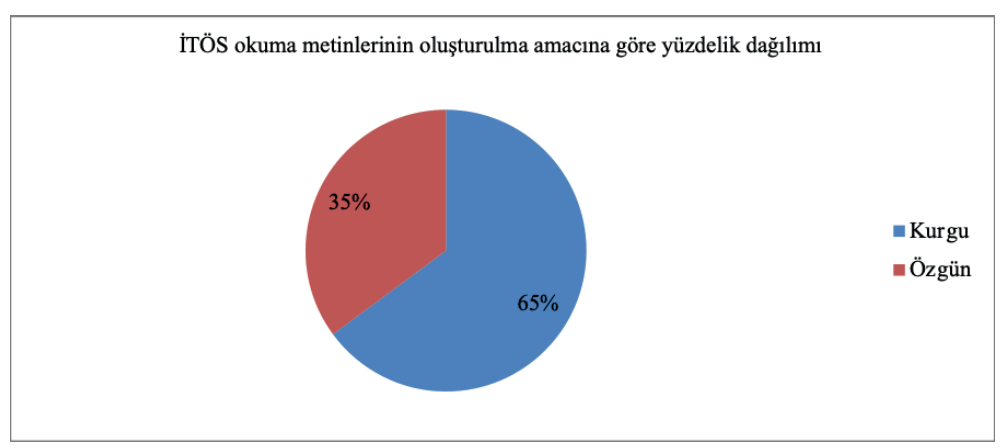

Şekil 4. İTÖS okuma metinlerinin oluşturulma amacına göre yüzdelik dağılımı

Oluşturulma amacina göre metin türlerine ait veriler incelendiğinde her iki set için de kurgu metinlerin özgün metinlerden çok daha fazla yer kapladığ́ görülmektedir. YİTÖS ders kitaplarında yer alan kurgu metinlerin toplam metin sayısına oranı \%81 iken İTÖS ders kitaplarındaki kurgu metinlerin toplam metin sayısına oranı \%65'tir. Bu bakımdan İTÖS ders kitaplarında oransal olarak özgün metinlere daha çok yer verildiği görülebilmektedir.

YİTÖS ders kitaplarında tüm seviyelerde özgün metinler yer almaktayken İTÖS A1 ders kitabında özgün metin bulunmamaktadır.

YİTÖS ve İTÖS ders kitaplarında özgün metinlerin seviye odaklı kullanımı ile ilgili bir sistematik yoktur.

Diller İçin Avrupa Ortak Öneriler Çerçevesi'nde ${ }^{23}$ yabancı dil öğretiminde kullanılacak metinlerin salt dil öğretimi için hazırlanmış metinlerden değil; bildirişimsel amaçlar doğrultusunda üretilmiş özgün metinlerden oluşması gerektiği açık bir şekilde belirtilmektedir. Her iki sette yer alan metinlerin ağırlıklı olarak salt dil öğretimi için hazırlanmış kurgu metinlerden oluştuğu görülmektedir. Her iki sette de özellikle temel seviyede çok az sayıda özgün metnin yer aldığ 1 tespit edilmiştir. Özgün metinlerin temel seviyelerde orijinal şekilleriyle kullanıma uygun olmamasının ve özgün metinlerin temel seviyelere göre uyarlanmasının zor olmasının temel seviyelerde özgün metinlerin az kullanılmasına neden olduğu düşünülmektedir.

Yabancı dil öğretiminde seviye yükseldikçe özgün metinlerin orijinal hâlleriyle kullanımları mümkün olmakta ve metinlerin seviyelere göre uyarlanması da kolaylaşmaktadır. İTÖS B1 ders kitabında özgün ve kurgu metinlerin sayısının birbirine eşit olması bu duruma örnek teşkil etmektedir. Ancak her iki sette de özgün metinler C1 seviyesi de dâhil olmak üzere kurgu metinlerin sayısını geçmemiştir. Bu durum her iki set içinde bir eksiklik olarak karşımıza çıkmaktadır. Özgün metinlerin ileri seviyelerde oransal olarak kurgu metinlerden daha az olması, kitap yazarlarının özgün metin kullanmaya özen göstermemiş olmalarına dayandırılmaktadır.

23 Avrupa Konseyi/Modern Diller Bölümü, Diller İçin Avrupa Ortak Öneriler Çerçevesi Öğrenim, Öğretim ve Değerlendirme, 2013, 146. 


\section{2. İşlevlerine Göre Metin Türlerine İlişkin Bulgular}

Metin türleri işlevleri açısından ele alındığında kullanım işlevli metinler, edeb̂̂ metinler ve diğer olmak üzere üç başlıkta tasnif edilmektedir.

İşlevlerine göre metinler ile ilgili seviye odaklı veriler aşağıda yer almaktadır:

\section{Tablo 7.}

Okuma Metinlerinin İşlevlerine Göre Dağılımı

\begin{tabular}{|c|c|c|c|c|c|}
\hline \multicolumn{6}{|c|}{ İşlevlerine Göre Metinler } \\
\hline Seviye & Öğretim Seti & Kullanım İşlevli & Edebî & Diğer & Toplam \\
\hline \multirow[t]{2}{*}{ A1 Seviyesi } & YİTÖS & 62 & 20 & 6 & 88 \\
\hline & İTÖS & 15 & 5 & 2 & 22 \\
\hline \multirow[t]{2}{*}{ A2 Seviyesi } & YİTÖS & 55 & 18 & 1 & 74 \\
\hline & İTÖS & 15 & 8 & 1 & 24 \\
\hline \multirow[t]{2}{*}{ B1 Seviyesi } & YİTÖS & 58 & 22 & 4 & 84 \\
\hline & İTÖS & 7 & 17 & 0 & 24 \\
\hline \multirow[t]{2}{*}{ B2 Seviyesi } & YİTÖS & 30 & 31 & 2 & 63 \\
\hline & İTÖS & 4 & 19 & 0 & 23 \\
\hline \multirow[t]{2}{*}{ C1 Seviyesi } & YİTÖS & 26 & 40 & 1 & 67 \\
\hline & İTÖS & 10 & 27 & 1 & 38 \\
\hline \multirow[t]{2}{*}{ Toplam } & YİTÖS & 231 & 131 & 14 & 376 \\
\hline & ITÖS & 51 & 76 & 4 & 131 \\
\hline
\end{tabular}

\subsubsection{Metinlerin İşlevlerine Göre Seviye ve Genel Toplam Odaklı Sayısal ve Yüzdelik} Dağılımlarına İlişkin Bulgular

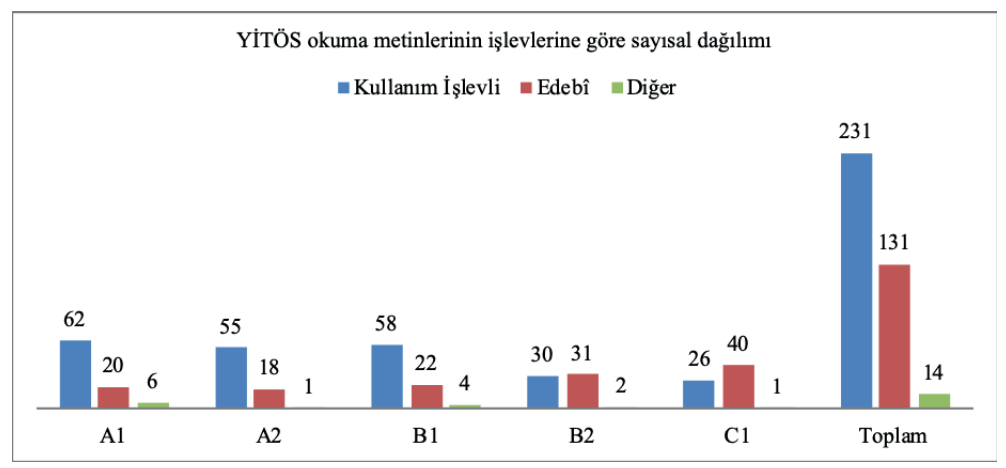

Şekil 5. YITÖO okuma metinlerinin işlevlerine göre sayısal dağılımı 


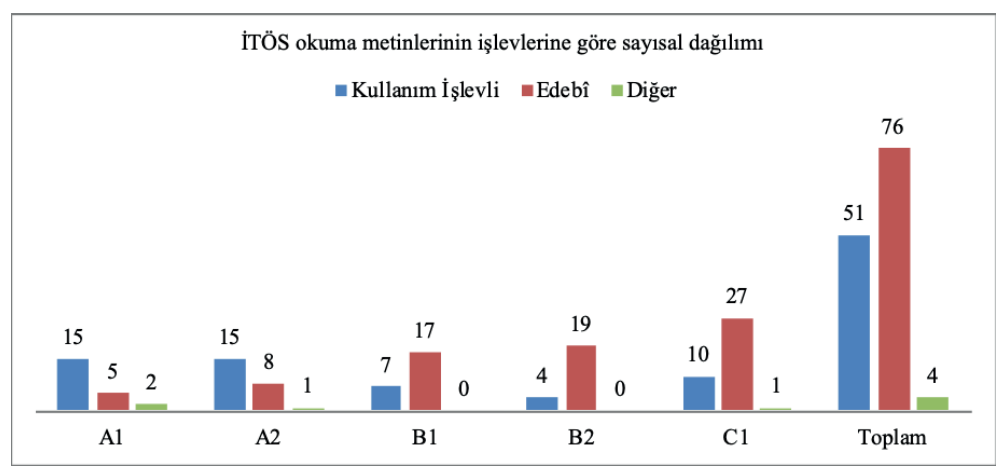

Şekil 6. İTÖS okuma metinlerinin işlevlerine göre sayısal dağılımı

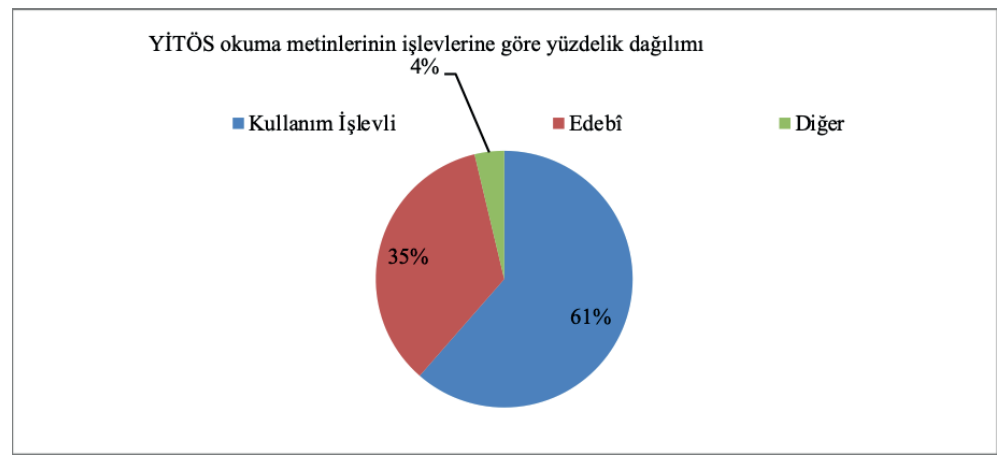

Şekil 7. YİTÖS okuma metinlerinin işlevlerine göre yüzdelik dağılımı

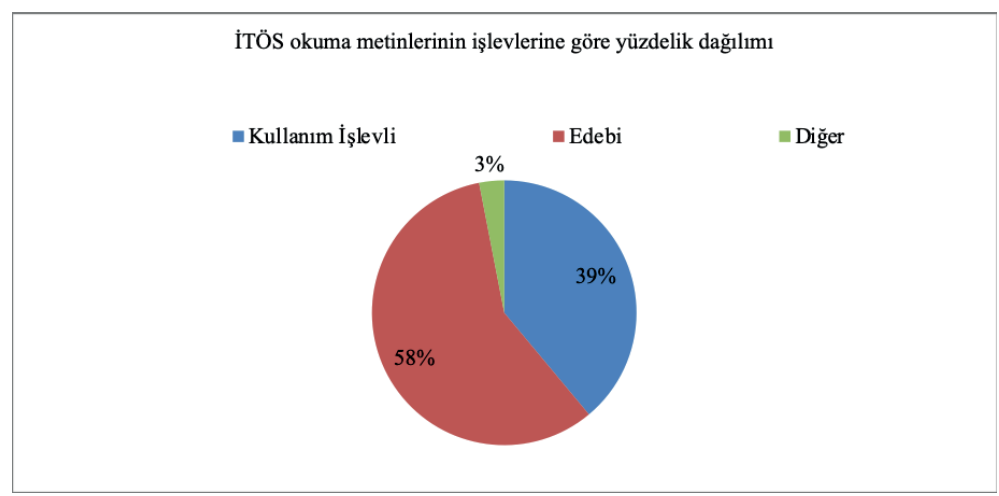

Şekil 8. İTÖS okuma metinlerinin işlevlerine göre yüzdelik dağılımı

Tablo ve grafikler incelendiğinde YİTÖS ders kitaplarında yer alan okuma metinlerinin 231'inin kullanım işlevli, 131'inin edebî, 14'ünün de diğer metin türleri tasnifi içerisinde yer aldığ 1 görülmektedir. İTÖS ders kitaplarında yer alan metinlerin ise 51'i kullanım işlevli, 76'sı edebî, 4'ü ise diğer metin türleri tasnifi içerisinde yer almaktadır. YİTÖS ders 
kitaplarında kullanım işlevli metinlerin sayısı edebî metinlerin sayısından daha fazla iken İTÖS ders kitaplarında edebî metinlerin sayısı kullanım işlevli metinlerin sayısından daha fazladır. Diğer metin türleri tasnifi içerisindeki metinler için ise YİTÖS'te 14, İTÖS'te 4 metin bulunmaktadır.

İşlevlerine göre metin türleri oransal olarak ele alındığında sayısal verilerdeki fazlalık ve azlıklar oransal olarak da benzer biçimde yansımaktadır. YİTÖS ders kitaplarında kullanım işlevli metinlerin oranı daha fazla iken İTÖS ders kitaplarında edebî metinlerin oranı daha fazladır. YİTÖS ders kitaplarında kullanım işlevli metin sayısının toplam metin sayısına oranı \%61,4; edebî metin sayısının toplam metin sayısına oranı \%34,8 iken İTÖS'te kullanım işlevli metinlerin oranı \%38,9, edebî metinlerin oranı \%58'dir.

YİTÖS ders kitaplarında seviye yükseldikçe edebî metinlerin kullanımındaki oran da yükselmektedir. YİTÖS ders kitaplarında edebî metinler; A1 seviyesinde \%22,7; A2 seviyesinde $\% 24,3$; B1 seviyesinde $\% 26,1$; B2 seviyesinde $\% 49,2$; C1 seviyesinde $\% 59,7$ oranındadır.

İTÖS ders kitaplarında edebî metinlerin kullanım oranı A1 seviyesinden itibaren B2 seviyesi de dâhil olmak üzere artmakta ancak C1 seviyesinde B2 seviyesine göre oransal olarak azalmaktadır. İTÖS ders kitaplarında edebî metinler; A1 seviyesinde \%22,7; A2 seviyesinde $\% 33,3$; B1 seviyesinde \%70,8; B2 seviyesinde \%82,6; C1 seviyesinde \%71 oranındadır.

Edebî metinlerin oranı İTÖS ders kitaplarında B1, B2 ve C1 seviyelerinde kullanım işlevli metinlerin oranından daha fazladır. YİTÖS’te ise edebî metinler B2 ve C1 seviyesinde kullanım işlevli metinlerden oransal olarak daha fazladır.

Kullanım işlevli metinlerin temel seviyelerde edebî metinlerden daha fazla kullanılmasının sebebi söz konusu metinlerin günlük hayat kullanımlarına daha uygun olmasından ve öğrencilerin iletişimsel beceri geliştirmelerine daha kolay olanak sağlamasından kaynaklandığ 1 düşünülmektedir.

"Diğer" metin türü tasnifi içerisinde yer alan metinler ise herhangi bir metin türü tasnifi içerisine girmemiş metinlerdir. YİTÖS ders kitaplarındaki “diğer” metin türlerinin oranı \%3,7 iken İTÖS ders kitaplarındaki “diğer” metin türlerinin oranı \%3’tür.

\subsubsection{Metinlerin Kullanım İşlevli Metin ve Edebî Metin Olma Özelliklerine İliş̧kin Bulgular}

Metin türleri sınıflandırmasında kullanım işlevli metinler kendi içerisinde resmî yazılar, öğretici metinler ve iletişimsel metinler olarak üçe; edebî metinler kendi içerisinde öğretici metinler, anlatmaya/göstermeye dayalı metinler ve nazım olmak üzere yine üçe ayrılmaktadır. Bu iki sınıflandırma içerisinde de yer almayan metinler diğer başlığı altında toplanmıştır.

Yukarıda adı geçen metin türleri ile ilgili veriler, seviye odaklı olarak aşağıda yer almaktadır: 
Tablo 8.

Okuma Metinlerinin Kullanım İşlevli Metin ve Edebî Metin Olma Özelliklerine Göre Dağılımı

Kullanım İşlevli ve Edebî Metin Türleri

\begin{tabular}{|c|c|c|c|c|c|c|c|c|c|}
\hline & Seviye & $\begin{array}{l}\text { Resmî } \\
\text { yazılar }\end{array}$ & $\begin{array}{l}\text { Öğretici } \\
\text { metinler } \\
\text { (KİM) }\end{array}$ & $\begin{array}{l}\text { İletişimsel } \\
\text { metinler }\end{array}$ & $\begin{array}{l}\text { Öğretici } \\
\text { metinler } \\
\text { (Edebî) }\end{array}$ & $\begin{array}{l}\text { Anlatmaya/ } \\
\text { Göstermeye } \\
\text { dayalı metinler }\end{array}$ & Nazım & Diğer & Toplam \\
\hline \multirow[t]{2}{*}{ A1 Seviyesi } & YİTÖS & & 22 & 40 & 18 & 1 & 1 & 6 & 88 \\
\hline & İTÖS & & 9 & 6 & 5 & & & 2 & 22 \\
\hline \multirow[t]{2}{*}{ A2 Seviyesi } & YİTÖS & & 23 & 32 & 15 & 3 & & 1 & 74 \\
\hline & İTÖS & & 7 & 8 & 3 & 5 & & 1 & 24 \\
\hline \multirow[t]{2}{*}{ B1 Seviyesi } & YİTÖS & 3 & 34 & 21 & 17 & 3 & 2 & 4 & 84 \\
\hline & İTÖS & & 3 & 4 & 15 & 2 & & & 24 \\
\hline \multirow[t]{2}{*}{ B2 Seviyesi } & YİTÖS & 1 & 22 & 7 & 26 & 4 & 1 & 2 & 63 \\
\hline & İTÖS & & 4 & & 17 & 2 & & & 23 \\
\hline \multirow[t]{2}{*}{ C1 Seviyesi } & YİTÖS & & 25 & 1 & 30 & 7 & 3 & 1 & 67 \\
\hline & İTÖS & & 8 & 2 & 18 & 6 & 3 & 1 & 38 \\
\hline \multirow[t]{2}{*}{ Toplam } & YİTÖS & 4 & 126 & 101 & 106 & 18 & 7 & 14 & 376 \\
\hline & İTÖS & & 31 & 20 & 58 & 15 & 3 & 4 & 131 \\
\hline
\end{tabular}

5.2.3. Metinlerin Kullanım İşlevli Metin ve Edebî Metin Olma Özelliklerine Göre Seviye ve Genel Toplam Odaklı Dağılımlarına İlişkin Bulgular

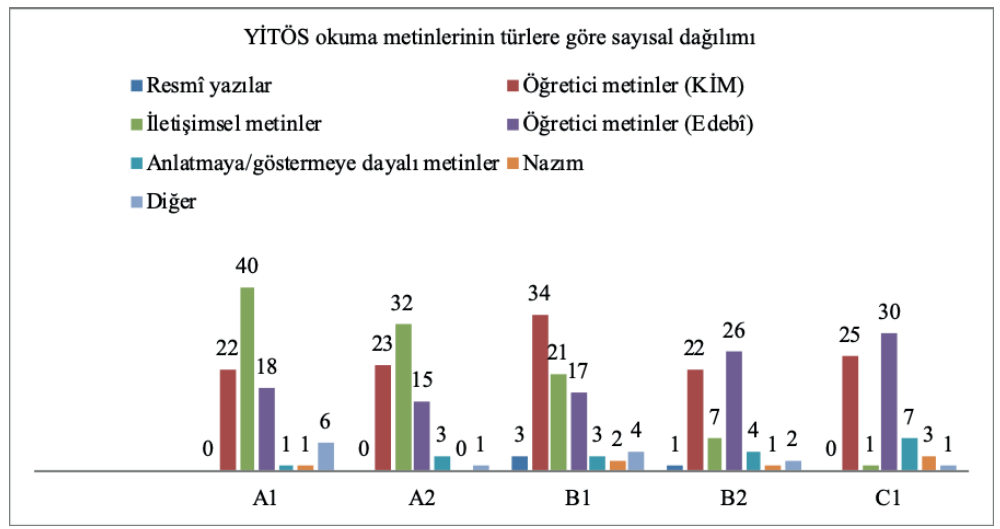

Şekil 9. YİTÖS okuma metinlerinin türlere göre sayısal dağılımı 


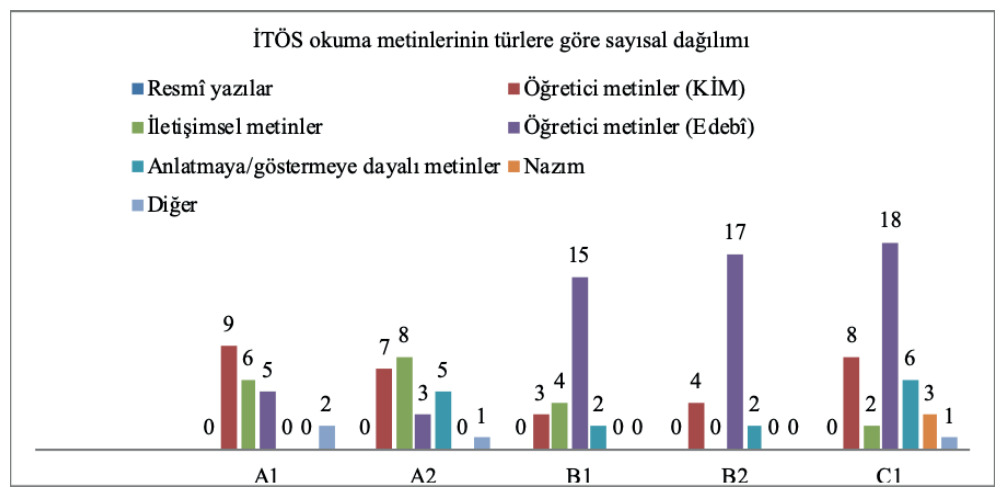

Şekil 10. İTÖS okuma metinlerinin türlere göre sayısal dağılımı

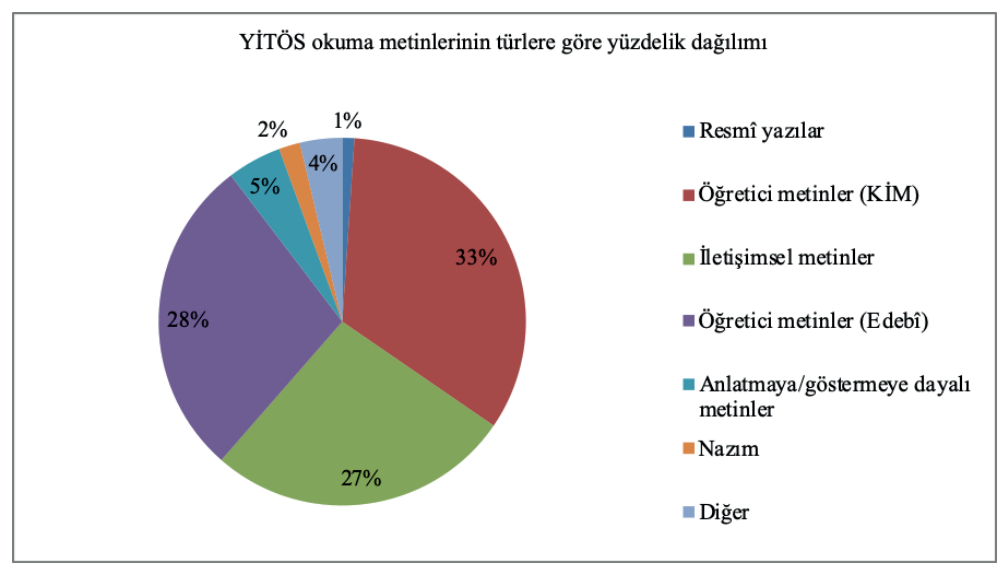

Şekil 11. YİTÖS okuma metinlerinin türlere göre yüzdelik dağılımı

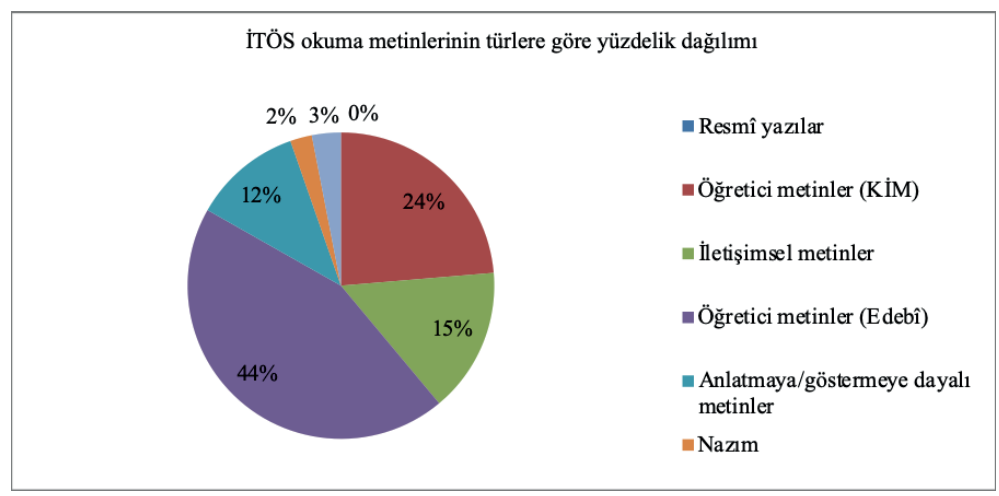

Şekil 12. İTÖS okuma metinlerinin türlere göre yüzdelik dağılımı 
Tablo ve grafikler incelendiğinde YİTÖS ders kitaplarında kullanım işlevli metin türlerinin daha fazla kullanıldığı, İTÖS ders kitaplarında edebî metin türlerinin daha fazla kullanıldı̆̆ görülmektedir.

YİTÖS ders kitaplarında oransal olarak en yaygın kullanım alanına sahip metin türünü \%33 ile öğretici metinler (KİM) oluşturmaktadır. Öğretici metinleri sırasıyla \%28 ile öğretici metinler (edebî), \%27 ile iletişimsel metinler, \%5 ile anlatmaya/göstermeye dayalı metinler, $\% 4$ ile diğer, \%2 ile nazım, \%1 ile resmî yazılar takip etmektedir.

İTÖS ders kitaplarında oransal olarak en yaygın kullanım alanına sahip metin türünü \%44'lük bir oran ile öğretici metinler (edebî) oluşturmaktadır. Öğretici metinler (edebî)'i sırasıyla \%24 ile öğretici metinler (KİM), \%15 ile iletişimsel metinler, \%12 ile anlatmaya/ göstermeye dayalı metinler, \%3 ile diğer, \%2 ile nazım takip etmektedir.

Resmî yazıların İTÖS ders kitaplarında hiç kullanılmadığı görülürken YİTÖS ders kitaplarında B1 seviyesinde 3 defa, B2 seviyesinde ise 1 defa kullanıldığ1 görülmektedir. Resmî yazıların İTÖS ders kitaplarında hiç kullanılmaması, YİTÖS ders kitaplarında ise ilk kullanımının B1 seviyesinde olması ve toplamda çok az sayıda kullanılması olumsuz karşılanabilecek bir durumdur. Çünkü Türkiye'ye gelmek isteyen veya Türkiye'de bulunan yabancılar doğal olarak resmî yazılarla karşılaşmaktadır. Resmî yazıların dilinin ağır olması ve seviyelere göre uyarlanmaya elverişli olmaması bu tür metinlere öğretim setlerinde çok az yer verilmesine neden olmaktadır. Ancak yabancı dil öğrenenler için elzem metin türlerinden birini oluşturan resmî yazıların YİTÖS ders kitaplarında temel seviyede sade ve basit olanlarının kullanılmaması; İTÖS ders kitaplarında ise hiç kullanılmaması olumsuz karşılanabilecek bir durumdur.

Metin türlerinin hangi seviyelerde hangi oranlarda kullanıldığ 1 da önem arz eden bir diğer konudur.

YİTÖS A1 seviyesinde iletişimsel metinler \%45,4; öğretici metinler (KİM) \%25, öğretici metinler (edebî) \%20,4; diğer \%6,8; anlatmaya/göstermeye dayalı metinler \%1,1; nazım \%1,1 oranında kullanılmış, resmî yazılar kullanılmamıştır. İTÖS A1 seviyesinde ise öğretici metinler (KİM) \%40,9; iletişimsel metinler \%27,2; öğretici metinler (edebî) \%22,7; diğer \%9 oranında kullanılmış, resmî yazılar, anlatmaya göstermeye dayalı metinler ve nazım ise kullanılmamıştır.

YİTÖS A2 seviyesinde iletişimsel metinler \%43,2; öğretici metinler (KİM) \%31, öğretici metinler (edebî) \%20,2; anlatmaya/göstermeye dayalı metinler \%4, diğer \%1,3 oranında kullanılmış, resmî yazılar ve nazım kullanılmamıştır. İTÖS A2 seviyesinde ise iletişimsel metinler \%33,3; öğretici metinler (KİM) \%29,1; anlatmaya/göstermeye dayalı metinler \%20 ,8; öğretici metinler (edebî) \%12,5; diğer \%4,1 oranında kullanılmış, nazım ve resmî yazılar ise kullanılmamıştır.

YİTÖS B1 seviyesinde öğretici metinler (KİM) \%40,4; iletişimsel metinler \%25, öğretici metinler (edebî) \%20,2; anlatmaya/göstermeye dayalı metinler \%3,5; diğer \%4,7; resmî yazılar \%3,5; nazım \%2,3 oranında kullanılmıştır. İTÖS B1 seviyesinde ise öğretici metinler (edebî) 
\%62,5; iletişimsel metinler \%16,6; öğretici metinler (KİM) \%12,5; anlatmaya göstermeye dayalı metinler \%8,3 oranında kullanılmış, resmî yazılar, diğer ve nazım kullanılmamıştır.

YİTÖS B2 seviyesinde öğretici metinler (edebî) \%41,2; öğretici metinler (KİM) \%34,9; iletişimsel metinler \%11,1; anlatmaya/göstermeye dayalı metinler $\% 6,3$; diğer $\% 3,1$; nazım \%1,5, resmî yazılar \%1,5 oranında kullanılmıştır. İTÖS B2 seviyesinde ise öğretici metinler (edebî) \%73,9; öğretici metinler (KİM) \%17,3; anlatmaya göstermeye dayalı metinler \%8,6; oranında kullanılmış, resmî yazılar, diğer, iletişimsel metinler ve nazım kullanılmamıştır.

YİTÖS C1 seviyesinde öğretici metinler (edebî) \%44,7; öğretici metinler (KİM) \%37,3; anlatmaya/göstermeye dayalı metinler \%10,4; nazım \%4,4; diğer \%1,4 iletişimsel metinler \%1,4 oranında kullanılmış, resmî yazılar kullanılmamıştır. İTÖS C1 seviyesinde ise öğretici metinler (edebî) \%47,3; öğretici metinler (KİM) \%21, anlatmaya/göstermeye dayalı metinler $\% 15,7$ nazım $\% 7,8$; iletişimsel metinler $\% 5,2$; diğer $\% 2,6$ oranında kullanılmış, resmî yazılar kullanılmamıştır.

Seviyelere göre dağılım incelendiğinde YİTÖS ders kitaplarında A1 ve A2 seviyelerinde iletişimsel metinlerin oran bakımından ilk sırayı aldı̆̆ı görülürken B1 seviyesinde öğretici metinler (KIM)'in, B2 ve C1 seviyelerinde öğretici metinler (edebî)'in oran bakımından ilk sırayı aldığı görülmektedir. İTÖS ders kitaplarında ise A1 seviyesinde öğretici metinler (KİM), A2 seviyesinde iletişimsel metinler, B1, B2 ve C1 seviyesinde öğretici metinler (edebî)'in oran bakımından ilk sırayı aldığı tespit edilmiştir.

Öğrencilerin iletişim ihtiyaçlarının karşılanmasının temel seviyelerde önem taşıması sebebiyle temel seviyelerde iletişimsel metinlerin kullanılmasının daha doğru olacağı düşünülmektedir. Dilin inceliklerinin öğrenilmeye başlandığı orta ve ileri seviyelerde ise edebî metinlerin kullanılmasına ağırlık verilmeye başlanması daha doğru olacaktır. Bu bakımdan YİTÖS belirtilen gereklilikleri karşılamaktadır. İTÖS ders kitaplarında ise iletişimsel metinler sadece A2 seviyesinde oran bakımından ilk sırayı almaktadır. İTÖS A1 ders kitabında iletişimsel metinlerin ilk sırada yer almaması öğrencilerin dil ihtiyaçlarındaki önceliklerine karşılık verilmediğini düşündürmektedir.

YİTÖS ders kitaplarında metin türlerine daha fazla yer verilmesi metin sayılarının İTÖS'e göre oldukça fazla olmasından kaynaklanmaktadır. 


\subsection{4. İşlevlerine Göre Metin Türlerinin Genel Toplamına İlişkin Bulgular}

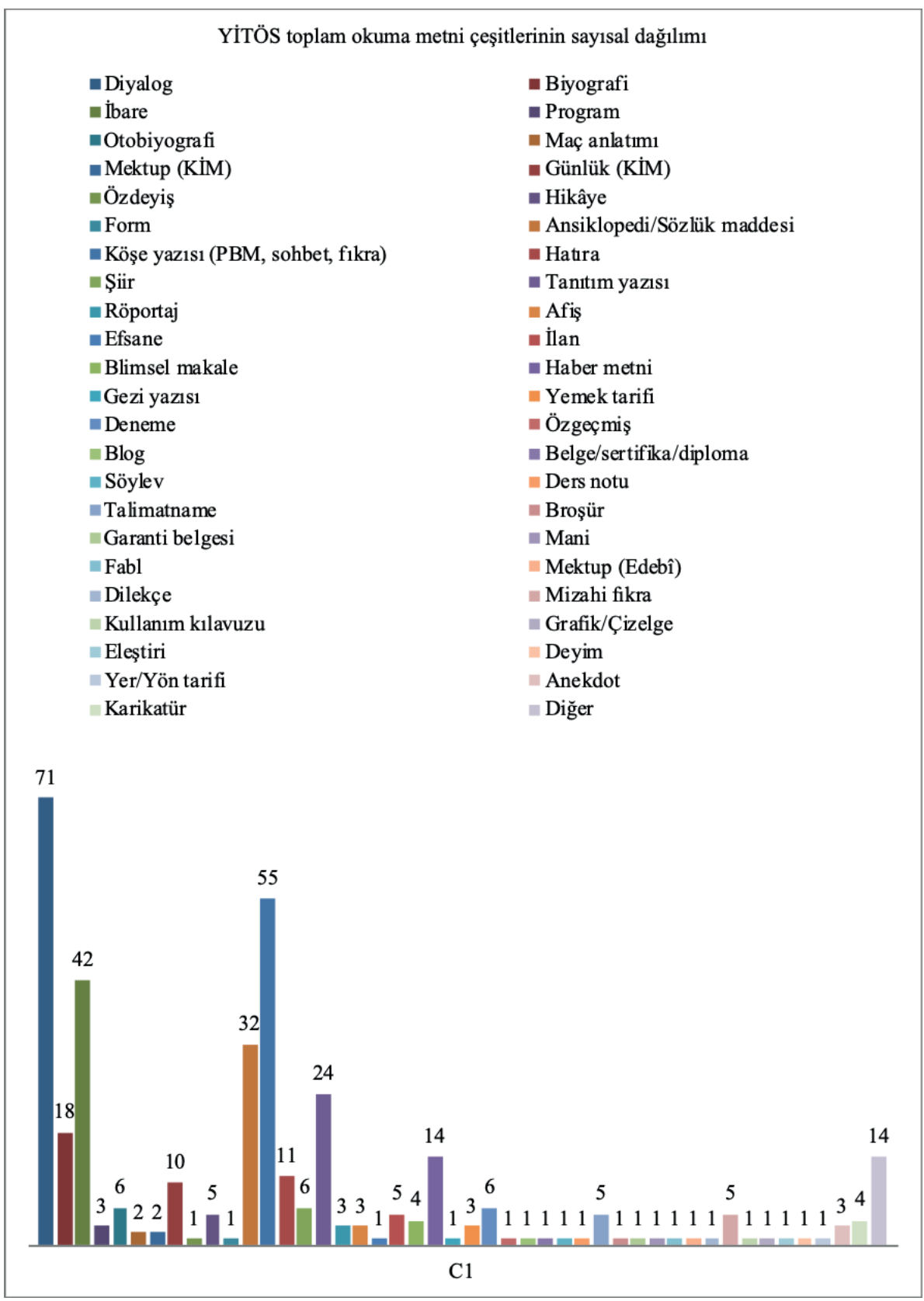

Şekil 13. YİTÖS toplam okuma metni çeşitlerinin sayısal dağılımı 


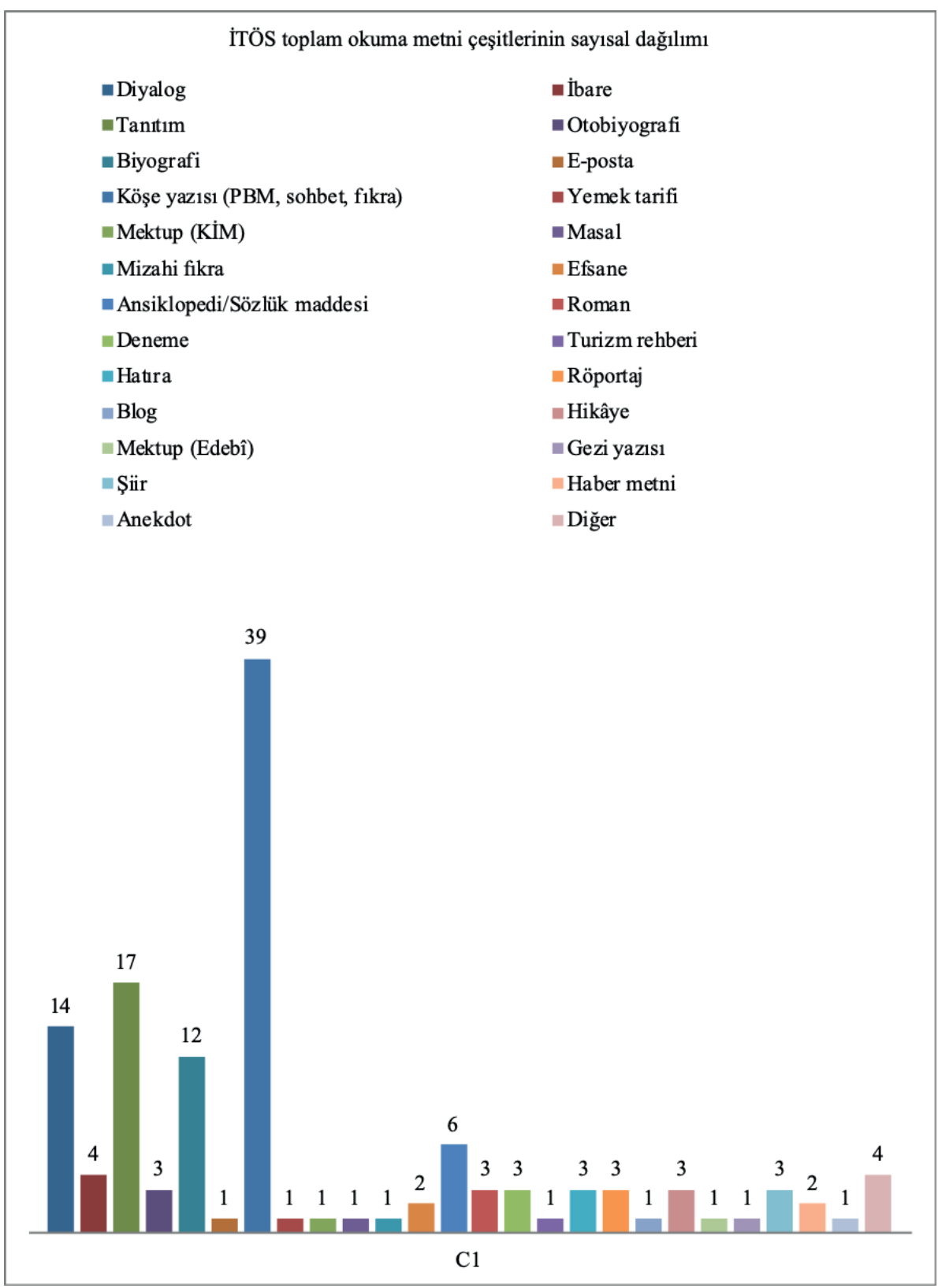

Şekil 14. İTÖS toplam okuma metni çeşitlerinin sayısal dağılımı 


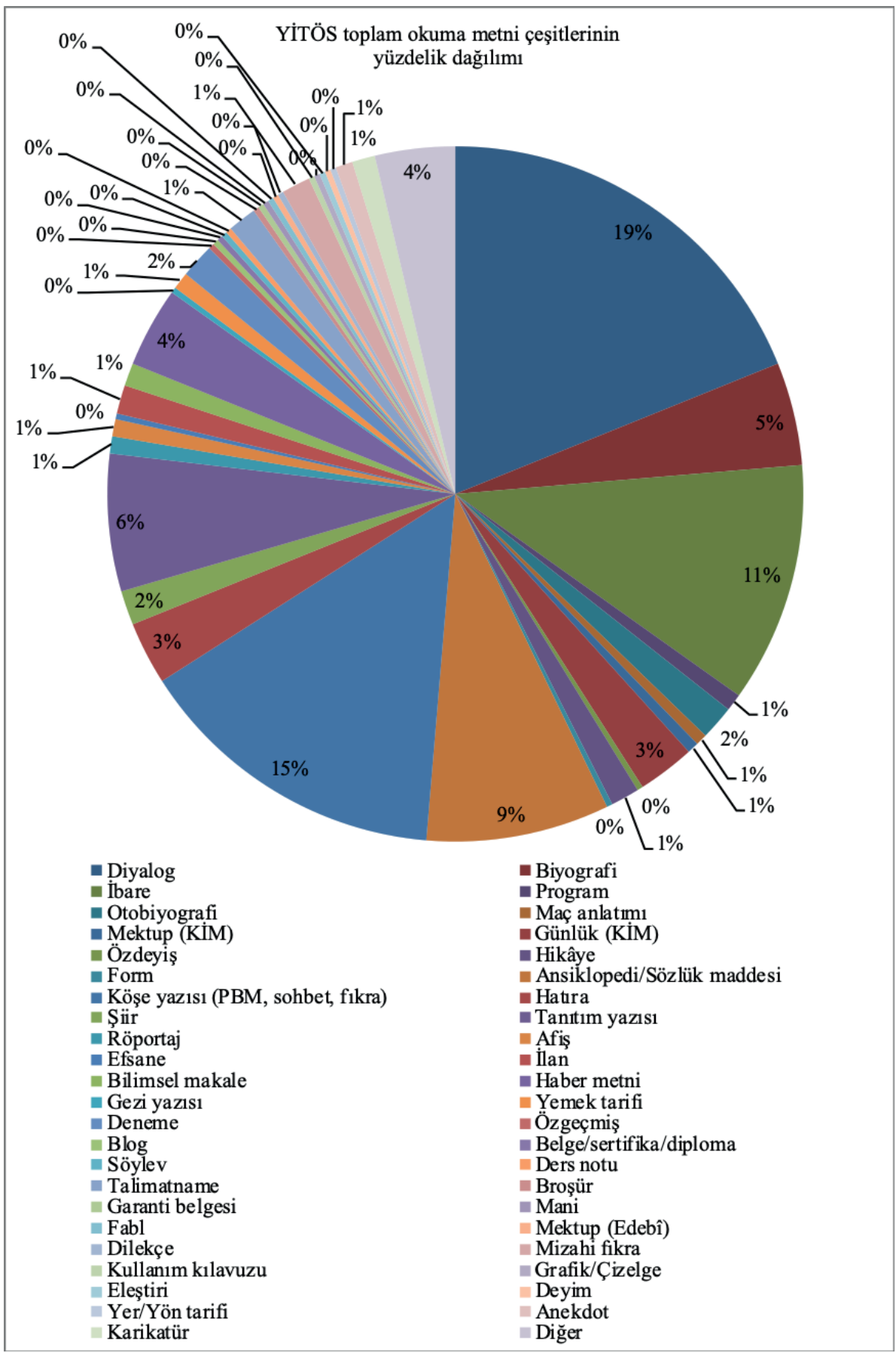

Şekil 15. YİTÖS toplam okuma metni çeşitlerinin genel dağılım yüzdesi 


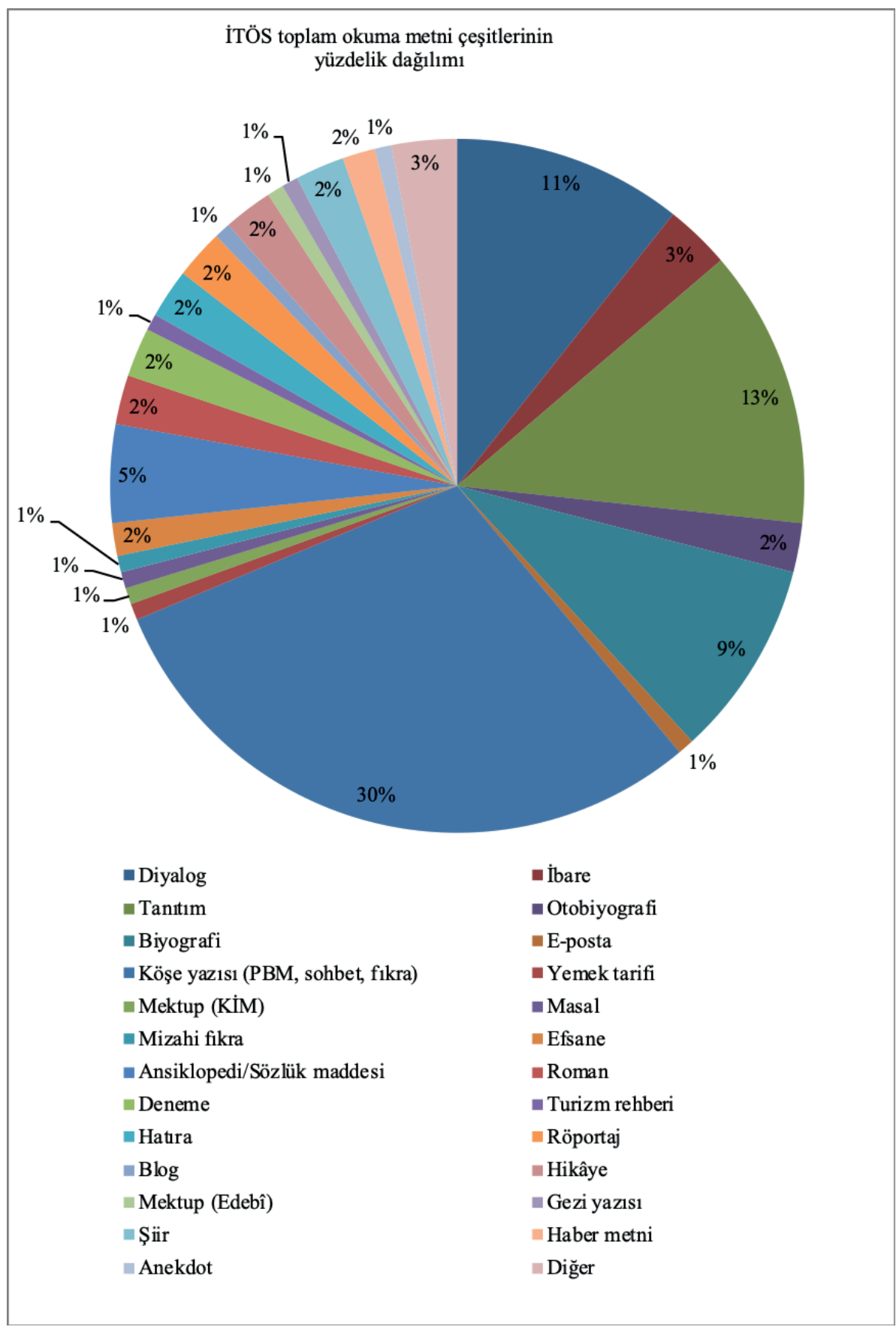

Şekil 16. İTÖS toplam okuma metni çeşitlerinin genel dağılım yüzdesi 
YİTÖS ders kitaplarında A1 seviyesinden C1 seviyesi tamamlana kadar toplamda 376 okuma metni yer almakta ve 46 farklı metin türü bulunmaktadır. İTÖS ders kitaplarında toplamda 131 okuma metni yer almakta ve 26 farklı metin türü bulunmaktadır. Metin türü çeşitliliğinin toplam metin sayısına oranı ele alınacak olursa İTÖS'ün metin çeşitliliği \%19,8 iken YİTÖS'ün \%12,2’dir. Bu bakımdan kullanılan metin türü çeşitliliğinin toplam metin sayısına oranı İTÖS'te daha yüksektir.

YİTÖS’te en çok kullanılan metin türü \%18,8 ile diyalogdur. Diyalogdan sonra \%14,6 ile köşe yazısı, \%11,1 ile ibare gelmektedir. İTÖS'te ise en çok kullanılan metin türü \%29,7 ile köşe yazısıdır. Köşe yazısından sonra \%12,9 ile tanıtım yazısı, \%10,6 ile diyalog yer almaktadır.

İbare, her iki sette de yer almakla birlikte YİTÖS’te $\% 11,1$ ile en yaygın kullanım alanına sahip üçüncü metin türüdür. İTÖS’teki kullanım alanı ise \%3 ile altıncı sıradadır.

Her iki öğretim setinde de okuma etkinlikleri içerisinde hiç kullanımına yer verilmemiş metinler de yer almaktadır. YİTÖS ders kitaplarında hiç kullanılmamış metin türleri şunlardır:

Resmî yazılar: Sözleşme/anlaşma, hukukî metinler (yasa, yönetmelik, yönerge vb.), rapor, tebligat, reçete.

Öğretici metinler (KIM): Bulmaca, harita, kroki, turizm rehberi, hava durumu, katalog.

İletişimsel metinler: E-posta, reklam, kartpostal, duvar yazısı, döviz, slogan/motto, sosyal medya mesajları, menü, davetiye.

Öğretici metinler (Edebî): Atasözü, dinî metin, günlük.

Anlatmaya/göstermeye dayalı metinler: Söyleşi, çizgi roman, masal, destan, roman.

Nazım: Ninni, şarkı, türkü, tekerleme, sayışmaca, bilmece.

İTÖS ders kitaplarında hiç kullanılmamış metin türleri ise şu şekildedir:

Resmî yazılar: Dilekçe, garanti belgesi, özgeçmiş, sözleşme/anlaşma, hukukî metinler (yasa, yönetmelik, yönerge vb.), rapor, tebligat, reçete, belge/diploma/sertifika.

Öğretici metinler (KIM): Ders notu, bulmaca, harita, kroki, kullanım kılavuzu, talimatname, hava durumu, katalog, çizelge/grafik, program (schedule).

İletişimsel metinler: Söylev, broşür, afiş, reklam, kartpostal, duvar yazısı, döviz, slogan (motto), ilan (emlak ve iş ilanları, duyuru), sosyal medya mesajları, form, menü, davetiye, maç anlatımı, günlük, yer/yön tarifi.

Öğretici metinler (edebî): Bilimsel makale, karikatür, atasözü, deyim, özdeyiş, eleştiri, dinî metin, günlük.

Anlatmaya/göstermeye dayalı metinler: Söyleşi, çizgi roman, fabl, destan.

Nazım: Mâni, ninni, şarkı, türkü, tekerleme, sayışmaca, bilmece.

YİTÖS ders kitaplarında kullanılmayan metin türlerinin sayısı 34, ITÖÖS ders kitaplarında ise 54'tür.

Resmî yazılardan YİTÖS’te sözleşme/anlaşma, hukukî metinler (yasa, yönetmelik, yönerge vb.), rapor, tebligat ve reçete, kullanılmamışken İTÖS’te dilekçe, garanti belgesi, özgeçmiş, sözleşme/anlaşma, hukukî metinler (yasa, yönetmelik, yönerge vb.), rapor, tebligat, reçete, belge/diploma/sertifika hiç kullanılmamıştır. 
Metin türleri tasnifinde resmî yazılar başlığı altında 9 metin türü bulunmaktadır. İTÖS’te resmî yazılardan hiçbiri kullanılmamışken YİTÖS’te 4 metin türü kullanılmıştır.

Hukukî metinler, rapor ve tebligat dil öğrenicileri tarafından günlük hayatta görülme olasılığı düşük metin türleri iken diğerleri Türkçe dil öğrenicileri tarafından günlük hayatta görülme olasılığg yüksek metin türleridir. Türkiye'de ev kiralamak isteyen bir kişi sözleşme ile karşılaşırken, herhangi bir belge talep etmek isteyen bir öğrenci dilekçeyle karşılaşabilmektedir. Herhangi bir ürün satın alan kişi garanti belgesiyle karşılaşırken bir iş başvurusu yapmak isteyen veya bir şahıs hakkında bilgi almak isteyen kişi özgeçmiş ile karşılaşır. Dil öğrenicisi doktora gittiğinde reçeteyle karşılaşırken birçok kurum ve kuruluşta belge, diploma veya sertifikayla karşılaşabilir. Ancak resmî yazılardan bu metin türlerinin okuma etkinlikleri içerisinde kullanılmamış olması bu metinlerin ders kitaplarında hiç yer almadığı anlamına da gelmemektedir. Örneğin, dilekçe okuma etkinliği içerisinde değil; yazma etkinliği içerisinde ders kitaplarında yer alabilir ve bu şekilde olması daha doğru olur. Fakat garanti belgesinin, reçetenin, belge/diploma/sertifika gibi metin türlerinin okuma becerisi dışında başka bir beceri etkinliği içerisinde yer alması düşünülemez.

Öğretici metinler (KIMM)'den YİTÖS'te bulmaca, harita, kroki, turizm rehberi, hava durumu, katalog kullanılmamışken İTÖS'te ders notu, bulmaca, harita, kroki, kullanım kılavuzu, talimatname, hava durumu, katalog, çizelge/grafik, program (schedule) kullanılmamıştır.

Metin türleri tasnifinde öğretici metinler (KİM) başlığı altında 16 farklı metin türü bulunmaktadır. YİTÖS'te toplamda 10 metin türü varken İTÖS'te 6 metin türü mevcuttur

İletişimsel metinlerden YİTÖS'te e-posta, reklam, kartpostal, duvar yazısı, döviz, slogan/ motto, sosyal medya mesajları, menü, davetiye; İTÖS'te söylev, broşür, afiş, reklam, kartpostal, duvar yazısı, döviz, slogan (motto), ilan (emlak ve iş ilanları, duyuru), sosyal medya mesajları, form, menü, davetiye, maç anlatımı, günlük, yer/yön tarifi hiç kullanılmamıştır.

Metin türleri tasnifinde iletişimsel metinler başlığ YİTÖS'te 12 metin türü; İTÖS'te 5 metin türü kullanılmıştır.

Öğretici metinler (edebî)'den YİTÖS’te atasözü, günlük ve dinî metin; İTÖS’te ise bilimsel makale, karikatür, atasözü, deyim, özdeyiş, eleştiri, dinî metin, günlük hiç kullanılmamıştır.

Metin türleri tasnifinde öğretici metinler (edebî) başlığı altında toplam 14 metin türü bulunmaktadır. YİTÖS'te 11 metin türü; İTÖS’te ise 6 metin türü kullanılmıştır.

Anlatmaya/göstermeye dayalı metinlerden YİTÖS'te söyleşi, çizgi roman, destan, masal, roman; İTÖS’te ise söyleşi, çizgi roman, fabl, destan hiç kullanılmamıştır.

Metin türleri tasnifi içerisinde anlatmaya göstermeye dayalı metinler başlığı altında toplam 11 metin türü bulunmaktadır. YITÖS'te 6 metin türü; İTÖS'te 7 metin türü kullanılmıştır.

Nazım başlığı altında yer alan metin türlerinden YITÖÖ’te ninni, şarkı, türkü, tekerleme, sayışmaca, bilmece; İTÖS’te ise mâni, ninni, şarkı, türkü, tekerleme, sayışmaca, bilmece hiç kullanılmamıştır.

Metin türleri tasnifinde nazım başlı̆̆ı altında 8 farklı metin türü bulunmaktadır. Bu metin türlerinden YİTÖS'te 2; İTÖS’te 1 tanesi kullanılmıştır. 


\section{Sonuç}

\subsection{Oluşturulma Amacına Göre Metin Türlerine İliş̧kin Sonuçlar}

1. YİTÖS ve İTÖS ders kitapları incelendiğinde her iki ders kitabında da kurgu metinlerin özgün metinlerden daha fazla yer aldığı tespit edilmiştir. YİTÖS ders kitaplarında 306 kurgu, 70 özgün metin varken İTÖS ders kitaplarında 85 kurgu, 46 özgün metin bulunmaktadır.

2. Her iki ders kitabında da seviye ilerledikçe özgün metinlerin sayısında genel itibarıyla bir artış mevcuttur. Ancak B2 seviyesinde her iki ders kitabında da özgün metinlerin sayısında bir azalma olduğu görülmüştür.

3. YITÖS ve İTÖS ders kitapları karşılaştırıldığında YİTÖS’te kullanılan özgün metinlerin toplam metin sayısına oranı \% 18,6 iken İTÖS’te bu oran \%35,1'dir. İTÖS ders kitaplarındaki özgün metinlerin kullanım oranı YİTÖS’ten daha fazladır.

4. Diller İçin Avrupa Ortak Öneriler Çerçevesi'nde ${ }^{24}$ metinlerin özel olarak dil öğretimi için hazırlanmış metinlerden değil; günlük hayattan alınmış iletişimsel amaçlı metinlerden oluşması gerektiği ifade edilmektedir. Öğretim setlerine ait ders kitapları bu bakımdan incelendiğinde her iki ders kitabının da yetersiz olduğu görülmektedir. Her iki öğretim setine ait temel seviyedeki ders kitaplarında özgün metinlerin kullanım oranı oldukça düşüktür. Bu durum özgün metinlerin temel seviyede orijinal şekilleriyle kullanıma çok uygun olmamasından ve metin uyarlama işlemleri açısından zorluklar taşımasından kaynaklanmaktadır. Öğretim setlerine ait ders kitaplarında orta ve ileri seviyelerde özgün metinlerin kullanım oranının temel seviyeye göre arttığı ancak kurgu metinlerin oranını geçmediği görülmektedir. Orta ve ileri seviyelerde özgün metinlerin kullanım oranının kurgu metinlerin kullanım oranından az olması kitap yazarlarının konuya gereken özeni göstermemesinden kaynaklanmaktadır. Her iki öğretim setinde de B1 seviyesindeki özgün metin oranının B2 seviyesinden daha yüksek olması ve İTÖS ders kitapları içerisinde özgün metinlerin kullanım oranının en yüksek olduğu seviyenin B1 seviyesi olması buna kanıt olarak gösterilebilir.

\section{2. İşlevlerine Göre Metin Türlerine İlişkin Sonuçlar}

1. YİTÖS ders kitaplarında yer alan okuma metinlerinin 231'inin kullanım işlevli, 131 'inin edebî, 14'ünün de diğer metin türleri tasnifi içerisinde yer aldı̆̆ı görülmektedir. İTÖS ders kitaplarında yer alan metinlerin ise 51'inin kullanım işlevli, 76'sının edebî, 4'ünün ise diğer metin türleri tasnifi içerisinde yer aldığı görülmektedir. Bu bakımdan YİTÖS ders kitaplarında yer alan okuma metinlerinin çoğunluğunun \%61,4 ile kullanım işlevli metin olduğu; İTÖS ders kitabında ise okuma metinlerinin çoğunluğunun \%58 ile edebî metin olduğu sonucuna ulaşılmıştır.

2. Her iki öğretim setinde A1 ve A2 seviyesinde kullanım işlevli metinlerin oranı daha yüksektir. Edebî metinlerin kullanım oranı İTÖS'te B1, B2 ve C1 seviyesinde daha fazla iken YİTÖS'te B2 ve C1 seviyesinde daha fazladır.

24 Avrupa Konseyi/Modern Diller Bölümü, Diller İçin Avrupa Ortak Öneriler Çerçevesi Öğrenim, Öğretim ve Değerlendirme, 2013, 146. 
3. Dil öğrenicilerinin temel seviyedeki dil ihtiyaçları daha çok pratik dil kullanımları etrafında toplanmaktadır. Kullanım işlevli metinler dil öğrenicilerinin gündelik ihtiyaçlarını gidermeye yönelik metinlerden oluşmaktadır. Bu bakımdan her iki öğretim seti temel seviyede dil öğrenicilerinin öncelikli ihtiyaçlarını gidermeye odaklanmıştır. Edebî metinler dil öğrenicilerinin daha çok dilin inceliklerini öğrenmelerine yardımcı olabilecek türden metinlerdir. Bu bakımdan orta seviyeden itibaren her iki öğretim seti de edebî metinlerin kullanımlarına ağırlık vermeye başlamıştır.

\subsection{Metinlerin Kullanım İşlevli Metin ve Edebî Metin Olma Özelliklerine İlişkin Sonuçlar}

1. Metin türleri; kullanım işlevli metin olma özelliklerine göre resmî yazılar, öğretici metinler ve iletişimsel metinler olmak üzere 3'e; edebî metin olma özelliklerine göre de öğretici metinler, anlatmaya/göstermeye dayalı metinler ve nazım olmak üzere 3'e ayrılmaktadır. YİTÖS ve İTÖS ders kitapları incelendiğinde YİTÖS ders kitaplarında genel kullanım bakımından ilk sırada \% 33,5 ile öğretici metinler (KİM) gelirken İTÖS ders kitaplarında \%44,2 ile öğretici metinler (edebî) gelmektedir.

2. YITTÖS ders kitaplarında kullanım oranı bakımından A1 ve A2 seviyesinde iletişimsel metinler, B1 seviyesinde öğretici metinler (KİM), B2 ve C1 seviyesinde öğretici metinler (edebî) ilk sırada yer almaktadır. İTÖS ders kitaplarında ise A1 seviyesinde öğretici metinler (KİM), A2 seviyesinde iletişimsel metinler, B1, B2 ve C1 seviyesinde öğretici metinler (edebî) ilk sirada yer almaktadır.

3. YİTÖS ve İTÖS ders kitaplarında A2, B2 ve C1 seviyelerinde kullanım oranı bakımından ilk sırada aynı metin türlerine yer verilmiştir. YİTÖS ve İTÖS öğretim setlerine ait A1 ve A2 ders kitaplarının her ikisinde de kullanım işlevli metinler ilk sırada yer almaktadır. YITTÖS A1 ve A2 seviyesinde kullanım oranı bakımından ilk sırada iletişimsel metinler yer alırken İTÖS'te A1 seviyesinde öğretici metinler (KİM), A2 seviyesinde iletişimsel metinler yer almaktadır. İletişimsel metinler dil öğrenicilerine günlük hayat içerisinde doğrudan iletişimsel becerileri kazandırmayı amaçlayan metinlerdir. Bu bakımdan YİTÖS A1 ve A2 seviyesinde oransal olarak bu tür metinlere daha çok yer vermişken İTÖS A1 seviyesinde iletişimsel metinler ikinci sırada yer almıştır. B1 seviyesinde YİTÖS kullanım işlevli metin türleri içerisinde yer alan öğretici metinlere daha çok yer vermişken İTÖS edebî metin türlerinden öğretici metinlere daha çok yer vermiştir.

\subsection{Metin Türlerine İlişkin Sonuçlar}

1. YİTÖS ders kitaplarında toplamda 376 okuma metni yer almakta olup 46 farklı metin türü bulunmaktadır. İTÖS ders kitaplarında ise toplamda 131 okuma metni yer almakta olup 26 farklı metin türü bulunmaktadır. İTÖS'te metin türü çeşitliliğinin toplam metin sayısına oranı \%19,8 iken YİTÖS'te \%12,2'dir. Bu bakımdan kullanılan metin 
türü çeşitliliği sayısal olarak ele alındığında YİTÖS’te, oransal olarak ele alındığında ise İTÖS'te daha yüksektir.

2. YİTÖS'te en çok kullanılan metin türü \%18,8 ile diyalogdur. Diyalogdan sonra $\% 14,6$ ile köşe yazısı, \%11,1 ile ibare gelmektedir. İTÖS’te ise en çok kullanılan metin türü \%29,7 ile köşe yazısıdır. Köşe yazısından sonra \% 12,9 ile tanıtım yazısı, \%10,6 ile diyalog yer almaktadır.

3. YİTÖS ders kitaplarında okuma etkinlikleri içerisinde yer alan okuma metinlerinde hiç kullanılmayan metin türlerinin sayısı 34, İTÖS ders kitaplarında ise 54'tür.

YİTÖS ders kitaplarında hiç kullanılmayan metin türleri şunlardır: Sözleşme/anlaşma, hukukî metinler (yasa, yönetmelik, yönerge vb.), rapor, tebligat, reçete, bulmaca, harita, kroki, turizm rehberi, hava durumu, katalog, e-posta, reklam, kartpostal, duvar yazısı, döviz, slogan/ motto, sosyal medya mesajları, menü, davetiye, atasözü, dinî metin, günlük, söyleşi, çizgi roman, masal, destan, roman, ninni, şarkı, türkü, tekerleme, sayışmaca, bilmece.

İTÖS ders kitaplarında hiç kullanılmayan metin türleri ise şunlardır: Dilekçe, garanti belgesi, özgeçmiş, sözleşme/anlaşma, hukukî metinler (yasa, yönetmelik, yönerge vb.), rapor, tebligat, reçete, belge/diploma/sertifika, ders notu, bulmaca, harita, kroki, kullanım kılavuzu, talimatname, hava durumu, katalog, çizelge/grafik, program (schedule), söylev, broşür, afişs, reklam, kartpostal, duvar yazısı, döviz, slogan (motto), ilan (emlak ve iş ilanları, duyuru), sosyal medya mesajları, form, menü, davetiye, maç anlatımı, günlük, yer/yön tarifi, bilimsel makale, karikatür, atasözü, deyim, özdeyiş, eleştiri, dinî metin, günlük, söyleşi, çizgi roman, fabl, destan, mâni, ninni, şarkı, türkü, tekerleme, sayışmaca, bilmece.

4. YİTÖS ve İTÖS ders kitapları incelendiğinde A1 seviyesinde YİTÖS'te en fazla kullanım oranına sahip metin türü diyalog iken İTÖS'te tanıtım yazısıdır. A2 seviyesinde her iki sette de en fazla kullanım alanına sahip metin türü diyalogdur. B1 seviyesinde YİTÖS’te en fazla kullanım alanına sahip metin türü diyalog iken İTÖS'te köşe yazısıdır. B2 ve C1 seviyesinde her iki sette de en fazla kullanım alanına sahip metin türü köşe yazısıdır. YİTÖS ve İTÖS'ün A2, B2 ve C1 ders kitaplarında en fazla kullanım alanına sahip metin türleri aynıdır. A1 seviyesi YİTÖS ders kitabında en fazla kullanım alanına sahip metin türü; dil öğrenicilerinin doğrudan hayata tutunabilmelerine olanak sağlayarak iletişimsel beceri geliştirmelerini amaçlayan diyaloglardır. İTÖS’te ise diyaloglar ikinci sırada yer alırken ilk sırayı tanıtım yazısı almıştır. B1 seviyesinde YİTÖS'te A1 ve A2 seviyelerinde olduğu gibi diyaloglar ilk sırayı alırken İTÖS’te B2 ve C1 seviyelerinde olduğu gibi ilk sırayı köşe yazıları almıştır. Köşe yazıları; popüler bilimsel makale, sohbet ve fikrayı içerisine alan öğretici metin (edebî) türüdür.

5. İletişimsel bağlamları itibarıyla zayıf özellikler gösteren ibareler, her iki sette de sıklıkla yer almaktadır. İbareler YİTÖS'te \%11 ile en yaygın kullanım alanına sahip üçüncü metin türü iken İTÖS'te \%3 ile en yaygın kullanım alanına sahip altıncı metin türüdür. Cümlecik terimi ile de kullanılan ibareler ders kitaplarında daha çok okuma başlığı altında yer alan dil bilgisi öğretimlerinin gerçekleştirildiği yerlerde ve kısa açıklama gerektiren durumlarda kullanılmıştır. 


\section{7. Öneriler}

Ders kitaplarında yer alan oluşturulma amacına göre metinler, Diller İçin Avrupa Ortak Öneriler Çerçevesi'nde ${ }^{25}$ de belirtildiği üzere ağırlıklı olarak özgün metinlerden oluşturulmalıdır. Özgün metinler doğrudan bildirişimsel amaçlar içermekte ve öğrencinin günlük hayatta karşılaşabileceği durumlara karşıllk gelmektedir. Ancak özgün metinlerin temel seviyede orijinal şekilleriyle kullanımlarında doğacak sıkıntılar ya da metin uyarlama işlemleri açısından zorluklar içermesi temel seviyede kurgu metinlerin kullanımına sebebiyet vermektedir. Ders kitabı yazarları orta ve ileri seviyelerde özgün metinleri kullanmalı, temel seviyede ise özgün metinlerin oranını geçmemek üzere kurgu metinlere de yer vermelidir.

İşlevlerine göre metin türlerinden kullanım işlevli metinler, dil öğrenicilerinin doğrudan gündelik hayat kullanımlarına yönelik metinler olduğu için temel seviyede edebî metinlerden daha fazla olmalıdır. Diller İçin Avrupa Ortak Öneriler Çerçevesi'nde ${ }^{26}$ B1 seviyesi okuma becerisi "İçlerinde her şeyden önce güncel yaşam ya da meslek dili geçen metinleri anlayabilirim. İçlerinde olaylardan, duygulardan, isteklerden söz edilen özel mektupları anlayabilirim." şeklinde tanımlanırken B2 seviyesi ise "Yazanların belirli bir tutum ve belirli bir konum izledikleri günümüz sorunlarıla ilgili makale ve raporları okuyabilir ve anlayabilirim. Çağdaş yazınsal düzyazı metinlerini anlayabilirim.” şeklinde tanımlanmaktadır. Bu bakımdan orta seviye içerisinde B1 seviyesinde kullanım işlevli metinler, B2 seviyesinde edebî metinler daha çok yer almalıdır.

Ders kitaplarında yer alan metinlerde, metin türlerine ait çeşitliliğin fazla olması, öğrencilerin hedef dilde karşılaşma olasılı̆̆ bulunan durumlar hakkında önceden bilgi sahibi olmasını sağlar. Bu bakımdan ders kitaplarında yer alan metinlerin farklı tür metinlerden oluşmasına özen gösterilmelidir. Ancak her seviyenin öğrenciye kazandırması gereken dil yeterliliklerinin farklı olması kullanılacak metin türlerini de etkilemektedir. A1 seviyesinde öğrencilerin hedef dilde hayata tutunmalarına olanak sağlayacak iletişimsel metinlere daha çok yer verilmesi gerekir. İletişimsel metinler içerisinde yer alan diyalog, sosyal medya mesajları, yer/yön tarifi, menü, e-posta, ilan (Emlak ve iş ilanları, duyuru, el ilanları), reklam gibi metin türleri dil öğrenicilerinin gündelik yaşam içerisinde sürekli karşılaşabilecekleri durumları gösterir. A2 seviyesinde A1 seviyesinde olduğu gibi iletişimsel metinlere ağıllık verilmeli, bunun yanında öğretici metinler (KIM)'e de yer verilmelidir. Öğretici metinler (KIM) içerisinde yer alan haber metni, hava durumu, program, tanıtım yazısı, harita, kroki, yemek tarifi, turizm rehberi gibi metin türleri öğrencilerin gündelik yaşamlarına yardımcı olabilecek durumları içerir. B1 seviyesi, öğrencilerin gündelik yaşam ihtiyaçlarını karşılayabilecek dil yeterliklerinin tamamlandığı seviye olarak karşımıza çıkmaktadır. Bu bakımdan kullanım işlevli metinlere bu seviye içerisinde edebî metinlerden daha çok yer verilmelidir. B2 seviyesi dil öğrenicilerinin

25 Avrupa Konseyi/Modern Diller Bölümü, Diller İçin Avrupa Ortak Öneriler Çerçevesi Öğrenim, Öğretim ve Değerlendirme, 2013, 146.

26 Avrupa Konseyi/Modern Diller Bölümü, Diller İçin Avrupa Ortak Öneriler Çerçevesi Öğrenim, Öğretim ve Değerlendirme, 2013, 32. 
hedef dildeki gündelik yaşam biçimlerini karşılayabilecek dil yeterliklerine sahip oldukları ve artık hedef dilin inceliklerini öğrenmeye başladıkları bir düzeydir. Bu seviyede bütün metin türlerine yer verilebileceği gibi daha çok edebî metinlere yer verilmelidir. Edebî metinler içerisinde anlatmaya/göstermeye dayalı metinlere ve öğretici metin (edebî)'lerden köşe yazısı (popüler bilimsel makale, sohbet, fikra)'na ağırlık verilebilir. C1 seviyesi dil öğrenicilerinin hedef dilde üst düzey yeterliklere sahip oldukları düzey olarak kabul edilmektedir. Bu seviyede dil öğrenicilerinin kendi uzmanlık alanında bulunmayan uzun ve karmaşık metinleri dahi anlayabildikleri kabul edilir. ${ }^{27} \mathrm{Bu}$ bakımdan $\mathrm{C} 1$ seviyesinde bütün metin türlerine yer verilmesi gerekir ancak ağırlıklı olarak edebî metinlere yer verilmesi daha doğru olur.

\section{Kaynaklar}

Avrupa Konseyi/Modern Diller Bölümü, Diller İçin Avrupa Ortak Öneriler Çerçevesi Öğrenim, Öğretim ve Değerlendirme, 2013. https://www.telc.net/fileadmin/user_upload/Publikationen/Diller_iain_Avrupa Ortak_oneriler_AEeraevesi.pdf sayfasından erişilmiştir.

Balc1, Ahmet. Okuma ve Anlama Eğitimi. Ankara: Pegem, 2013.

Barın Erol, Şaban Çobanoğlu, Şeref Ateş, Mustafa Balcı, ,Cihan Özdemir (Ed.). Yunus Emre Enstitüsü Türkçe Öğretim Seti A1 Ders Kitabı. Ankara: Merdiven Reklam Tanıtım, 2015.

Barın Erol, Şaban Çobanoğlu, Şeref Ateş, Mustafa Balcı, Cihan Özdemir (Ed.). Yunus Emre Enstitüsü Türkçe Ögretim Seti A2 Ders Kitabı. Ankara: Merdiven Reklam Tanıtım, 2015.

Barın Erol, Şaban Çobanoğlu, Şeref Ateş, Mustafa Balıı, Cihan Özdemir (Ed.). Yunus Emre Enstitüsü Türkçe Öğretim Seti B1 Ders Kitabı. Ankara: Merdiven Reklam Tanıtım, 2015.

Barın Erol, Şaban Çobanoğlu, Şeref Ateş, Mustafa Balcı, Cihan Özdemir (Ed.). Yunus Emre Enstitüsü Türkçe Ögretim Seti B2 Ders Kitabı. Ankara: Merdiven Reklam Tanıtım, 2015.

Barın Erol, Şaban Çobanoğlu, Şeref Ateş, Mustafa Balcı, Cihan Özdemir (Ed.). Yunus Emre Enstitüsü Türkçe Öğretim Seti C1 Ders Kitabı. Ankara: Merdiven Reklam Tanıtım, 2015.

Bölükbaş, Fatma, Mehmet Y. Yılmaz (Ed.), İstanbul Yabancılar İçin Türkçe A1 Ders Kitabı. İstanbul: Kültür Sanat, 2017.

Bölükbaş, Fatma, Mehmet Y. Yılmaz (Ed.). İstanbul Yabancılar İçin Türkçe A2 Ders Kitabı. İstanbul: Kültür Sanat, 2017.

Bölükbaş, Fatma, Mehmet Y. Yılmaz (Ed.). İstanbul Yabancılar İçin Türkçe B1 Ders Kitabı. İstanbul: Kültür Sanat, 2017.

Bölükbaş, Fatma, Mehmet Y. Yılmaz (Ed.). İstanbul Yabancılar İçin Türkçe B2 Ders Kitabı. İstanbul: Kültür Sanat, 2017.

Bölükbaş, Fatma, Mehmet Y. Yılmaz (Ed.). İstanbul Yabancılar İçin Türkçe C1 Ders Kitabı. İstanbul: Kültür Sanat, 2017.

Cemiloğlu, Mustafa. İlköğretim Okullarında Türkçe Öğretimi. Bursa: Alfa Aktüel, 2015.

Çetişli, İsmail. Edebiyat Sanatı ve Bilimi. Ankara: Akçağ, 2011.

27 Avrupa Konseyi/Modern Diller Bölümü, Diller İçin Avrupa Ortak Öneriler Çerçevesi Öğrenim, Öğretim ve Değerlendirme, 2013, 32. 
Demirel, Özcan. Yabancı Dil Öğretimi. Ankara: Pegem, 2012.

Dilidüzgün, Şükran. Metin Dilbilim ve Türkçe Öğretimi. Ankara: Anı, 2017.

Erkul, Rasih. Cümle ve Metin Bilgisi. Ankara: Anı, 2004.

Günay, Doğan. Metin Bilgisi. İstanbul: Papatya, 2013.

Güneş, Firdevs. Türkçe Öğretimi ve Zihinsel Yapılandırma. Ankara: Nobel, 2007.

Kavcar, Cavit, Ferhan Oğuzkan, Sedat Sever. Türkçe Öğretimi. Ankara: Engin, 1998.

Korkmaz, Cihat Burak. "Yabancı Dil Olarak Türkçenin Öğretiminde Kullanılan Dinleme Metinlerinin Metin İşleme Süreleri”, International Journal of Languages' Education and Teaching. 7/1, (2019): 121-146.

Korkmaz, Cihat, Burak. "Metin Sınıflandırması Bağlamında Yabancı Dil Olarak Türkçenin Öğretiminde Kullanılan Dinleme Metinleri”, Türkiyat Mecmuası, 29/1, (2019): 93-126.

Millî Eğitim Bakanlığı, Türkçe Dersi Öğretim Programı. Ankara, 2017.

Okur, Alparslan. “Türkçe Ders Kitabı Çözümlemeleri”, Ülper, Hakan. (Editör), Türkçe Ders Kitaplarında Metinlerin Türsel Özellikleri içinde s. 115- 140, Pegem, Ankara, 2104.

Ögeyik, Muhlise C. Metinlerarasılık ve Yazın Eğitimi. Ankara: Anı, 2008.

Öz, Feyzi M. Uygulamalı Türkçe Öğretimi. Ankara: Anı, 2001.

Saraçoğlu, Ahmet. Dil ve Edebiyat Terimleri Sözlüğü. Eskişehir: Etam, 2000.

Toprak, Funda. "Yabancılara Türkçe Öğretimi Kitaplarındaki Okuma Parçaları ve Diyaloglar Üzerine Bir Değerlendirme", Türkiyat Araştırmaları Dergisi. 29. (2011): 11-24. 